\title{
Measuring Systems Interoperability: Challenges and Opportunities
}

Mark Kasunic

William Anderson

April 2004

Software Engineering Measurement and Analysis Initiative

Unlimited distribution subject to the copyright.

Technical Note

CMU/SEI-2004-TN-003 
The Software Engineering Institute is a federally funded research and development center sponsored by the U.S. Department of Defense.

Copyright 2004 by Carnegie Mellon University.

NO WARRANTY

THIS CARNEGIE MELLON UNIVERSITY AND SOFTWARE ENGINEERING INSTITUTE MATERIAL IS FURNISHED ON AN "AS-IS" BASIS. CARNEGIE MELLON UNIVERSITY MAKES NO WARRANTIES OF ANY KIND, EITHER EXPRESSED OR IMPLIED, AS TO ANY MATTER INCLUDING, BUT NOT LIMITED TO, WARRANTY OF FITNESS FOR PURPOSE OR MERCHANTABILITY, EXCLUSIVITY, OR RESULTS OBTAINED FROM USE OF THE MATERIAL. CARNEGIE MELLON UNIVERSITY DOES NOT MAKE ANY WARRANTY OF ANY KIND WITH RESPECT TO FREEDOM FROM PATENT, TRADEMARK, OR COPYRIGHT INFRINGEMENT.

Use of any trademarks in this report is not intended in any way to infringe on the rights of the trademark holder.

Internal use. Permission to reproduce this document and to prepare derivative works from this document for internal use is granted, provided the copyright and "No Warranty" statements are included with all reproductions and derivative works.

External use. Requests for permission to reproduce this document or prepare derivative works of this document for external and commercial use should be addressed to the SEI Licensing Agent.

This work was created in the performance of Federal Government Contract Number F19628-00-C-0003 with Carnegie Mellon University for the operation of the Software Engineering Institute, a federally funded research and development center. The Government of the United States has a royalty-free government-purpose license to use, duplicate, or disclose the work, in whole or in part and in any manner, and to have or permit others to do so, for government purposes pursuant to the copyright license under the clause at 252.227-7013.

For information about purchasing paper copies of SEI reports, please visit the publications portion of our Web site (http://www.sei.cmu.edu/publications/pubweb.html). 


\section{Contents}

Executive Summary.........................................................................................

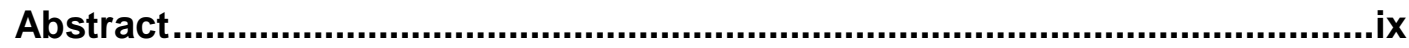

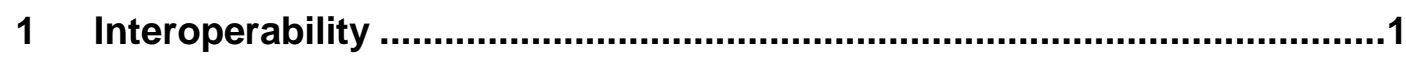

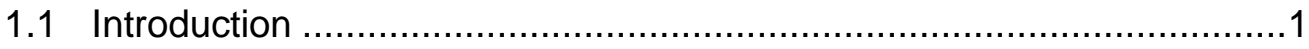

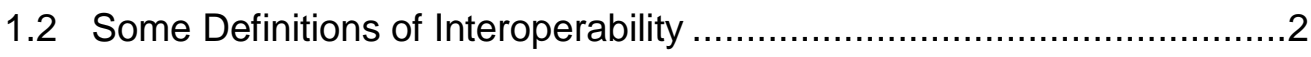

2 An Architectural Approach to Technical Interoperability .........................4

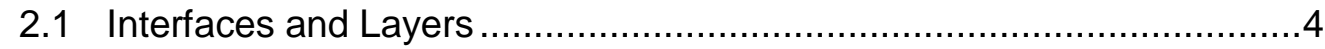

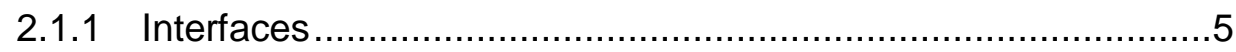

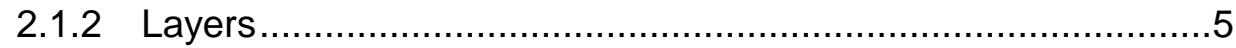

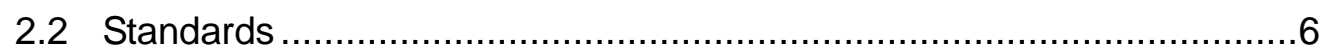

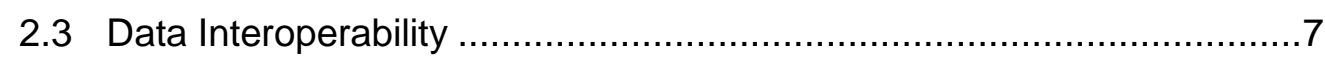

2.4 DoD Strategy for Addressing Interoperability ...................................

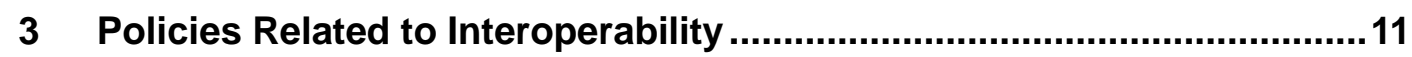

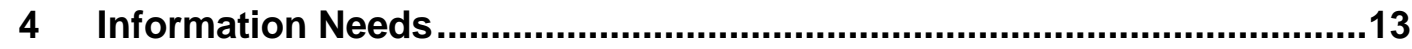

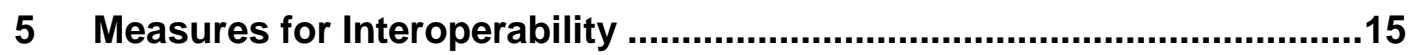

5.1 Levels of Information Systems Interoperability (LISI) ….....................16

5.1.1 Measuring Technical Compliance ..........................................22

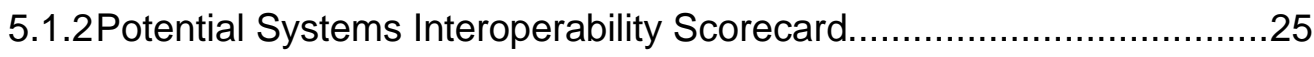

5.1.3Measuring Operational Interoperability ...........................................25

5.2 Management Measures Associated With Interoperability....................28

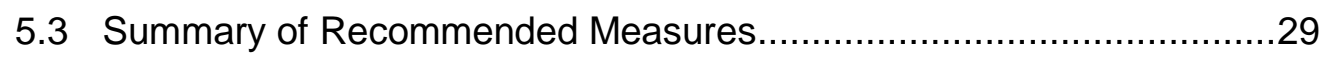

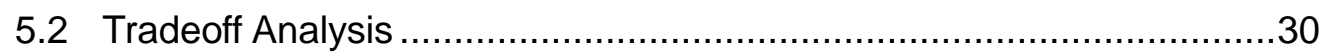

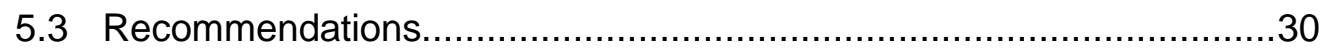

Appendix A Some Historical Definitions of Interoperability .......................32

Appendix B Testing Interoperability ..........................................................34 
Appendix C Potential Measures of Interoperability .................................. 37

Appendix D Equations for Quality Attributes Associated with the Interoperability Scorecard..................................................... 40

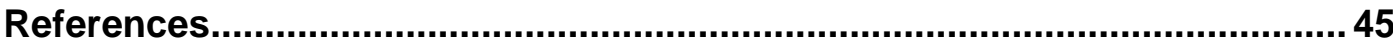




\section{List of Figures}

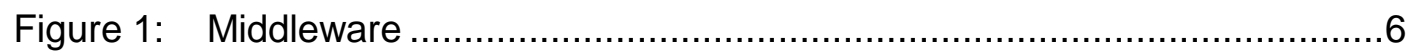

Figure 2: Three Views of an Architecture ................................................. 9

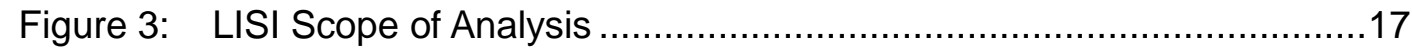

Figure 4: The LISI Interoperability Assessment Process ...................................22

Figure 5: Example Populated Interoperability Profile for 2c System ..................24

Figure 6: Example Systems Operability Scorecard .....................................25

Figure 7: Example of an Operational Interoperability Scorecard .......................26

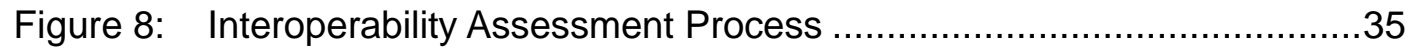




\section{List of Tables}

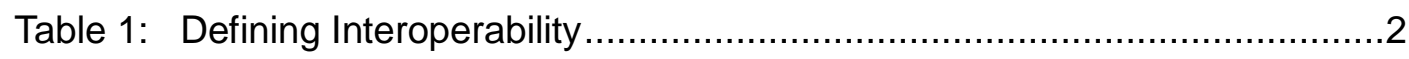

Table 2: Elements of the DoD Architectural Triad [C4ISR 97] ...........................

Table 3: Interoperability Entities for Agencies and Commands in the DoD.........13

Table 4: Overview of the LISI Interoperability Maturity Model ...........................18

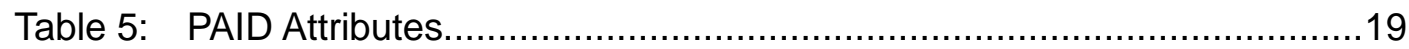

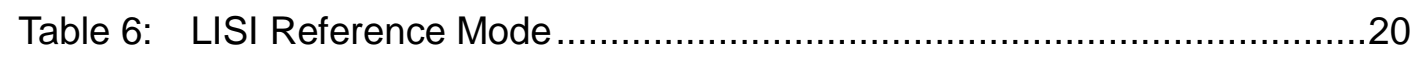

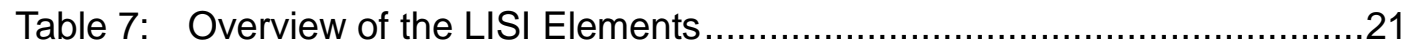

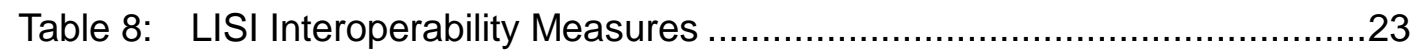

Table 9: Possible Formats for a LISI Measure ………...................................24

Table 10: Quality Attributes Associated with Interoperability ...............................27

Table 11: Summary of Recommended Measures..............................................29 


\section{Executive Summary}

Interoperability is the ability of systems, units, or forces to provide services to and accept services from other systems, units, or forces and to use the services exchanged to enable them to operate effectively together. The intent of this paper is to identify current practices related to measuring systems interoperability and to recommend a set of measures that will assist military planners in the acquisition, development, and implementation of command, control, communications, computers, and intelligence (C4I) systems that are interoperable.

In an April 1998 report to Congress, the Secretary of Defense noted that "joint operations have been hindered by the inability of forces to share critical information at the rate and at the locations demanded by modern warfare" [Hamilton 00]. Serious interoperability deficiencies have been perpetuated across all the services and have been identified in all recent, allied, joint, and combined operations and exercises.

Interoperability is a broad and complex subject. Developing and applying precise measurements in an area as multidimensional and complex as interoperability is difficult. However, measuring, assessing, and reporting interoperability in a visible way is essential to setting the right priorities. An increasing importance of and reliance on C4I support of military operations suggests the state and health of $\mathrm{C} 4 \mathrm{I}$ interoperability be characterized, as much as possible, in a more explicit, objective, and measurable way.

This technical note reviews the state of the practice in interoperability. The Levels of Systems Interoperability (LISI) Model is described. This model, although immature, provides a structured and systematic approach for assessing and measuring interoperability throughout the system life cycle. A summary of recommended measures that could promote systems interoperability in the Department of Defense (DoD) is also presented. 


\section{Abstract}

Despite laudable case-by-case efforts, there is today no method for tracking interoperability on a comprehensive or systematic basis. This technical note presents best practices for measuring systems interoperability and assisting military planners in the acquisition, development, and implementation of command, control, communications, computers, and intelligence (C4I) systems that are interoperable. The Levels of Systems Interoperability (LISI) Model, although immature, provides a structured and systematic approach for assessing and measuring interoperability throughout the systems life cycle. In addition to exploring the many complex issues surrounding the state of interoperability for military applications, next steps for promoting a deeper understanding of interoperability and recommended measures that will promote systems interoperability are presented. 


\section{Interoperability}

\subsection{Introduction}

Command, control, communications, computers, and intelligence (C4I) systems relay critical information to U.S. forces during joint operations.

In an April 1998 report to Congress, the Secretary of Defense noted that "joint operations have been hindered by the inability of forces to share critical information at the rate and at the locations demanded by modern warfare" [Hamilton 00].

Parts of the Department of Defense (DoD) are well aware of a defense-wide problem in exploiting rapidly changing information technologies. A DoD strategy is in place to promote interoperability, resting on technical standards such as the Joint Technical Architecture (JTA) and use of a defense-wide common infrastructure. While much has been accomplished, the goal of a C4I system of systems with interoperability for the U.S. military continues to be unachieved. Despite increased attention and management awareness, much more must be done before C4I interoperability provides adequate end-to-end support of military missions.

A popular perception is that interoperability is synonymous with connectivity. However, true interoperability is much more than just connectivity. It is also a function of operational concepts and scenarios, policies, processes, and procedures. For this reason, developing and applying precise measurements in an area as multidimensional and complex as interoperability is difficult. Interoperability is often considered to be a desired but unattainable goal rather than a condition that can be quantified [Leite 98]. Serious interoperability deficiencies exist today. They have been perpetuated across all the services and have been identified in all recent, allied, joint, and combined operations and exercises. Measurement and assessment - and the reporting of results in a visible way-are essential to setting the right priorities. As noted by Presson 21 years ago, "interoperability will never be an analytically useful field of study until it is defined in a quantitative way" [Presson 83]. Despite laudable case-by-case efforts, there is today no method for tracking interoperability on a comprehensive or systematic basis [Committee 99]. 


\subsection{Some Definitions of Interoperability}

A number of reports and technical papers offer definitions of interoperability. ${ }^{1}$ Recently, a Joint Chiefs of Staff publication [DoD 98] defined interoperability to acknowledge both technical and operational components.

\section{Table 1: Defining Interoperability}

\begin{tabular}{|l|l|}
\hline Operational Interoperability & $\begin{array}{l}\text { The ability of systems, units, or forces to provide services to } \\
\text { and accept services from other systems, units, or forces and } \\
\text { to use the services so exchanged to enable them to operate } \\
\text { effectively together [DoD 95, DoD 98]. }\end{array}$ \\
\hline Technical Interoperability & $\begin{array}{l}\text { The ability of systems, units, or forces to provide services to } \\
\text { or access services from other systems, units, or forces, and } \\
\text { use the services to operate effectively together [DoD 96]. }\end{array}$ \\
\hline $\begin{array}{l}\text { The condition achieved among communications-electronics } \\
\text { when information or services can be exchanged directly and } \\
\text { satisfactorily between them and/or their users. The degree of } \\
\text { interoperability should be defined when referring to specific } \\
\text { cases [DoD 98]. }\end{array}$ \\
$\begin{array}{l}\text { Interoperability is the ability of systems to provide dynamic } \\
\text { interactive information and data exchange among C4I nodes } \\
\text { for planning, coordination, integration, and execution of } \\
\text { Theater Air Missile Defense operations [JTAMDO 97]. }\end{array}$ \\
\hline
\end{tabular}

Operational interoperability addresses support to military operations and, as such, goes beyond systems to include people and procedures, interacting on an end-to-end basis. Implementation of operational interoperability therefore implies both the traditional approach of defining standards as well as enabling and assuring activities such as testing and certification, configuration, and version management, and training [Committee 99].

Interoperability at the technical level is essential to achieving operational interoperability. Technical interoperability occurs between systems (as opposed to organizations) and should be considered in a variety of contexts and scopes. Dimensions of technical interoperability include

- sensors generating bits of information

\footnotetext{
1 More information on this topic is available in Appendix A.
} 
- communication channels transmitting the bits of information

- computers processing the bits of information

- weapons directed by messages composed of bits

For two C4I systems to effectively interoperate, they must be able to exchange relevant bitstreams as well as to interpret the bits they exchange according to consistent definitions. Thus, technical interoperability places detailed demands at multiple levels, which range from physical interconnection to correct interpretation by applications of data provided by other applications [Committee 99]. 


\section{An Architectural Approach to Technical Interoperability}

The architecture of a system is the structure or structures of the system that comprise the components, the externally visible properties of those components, and the relationships among them [Bass 98]. Using measurement to assess the behavior of the key attributes of these components (and the relationships between them) is a daunting task. An architectural perspective helps to organize the complexity of the interoperability challenge in ways that can lead to more coherent treatments.

Architectures are a hierarchical description for the design of a system and in many cases describe how it will be developed, evolved, and operated. Architectures provide the underlying blueprint for the more detailed design and implementation decisions about the components of a system. When well-defined architectures exist, engineers can design individual components and builders can implement them with a high degree of confidence that the end results will work as expected and meet user needs.

There are a number of architectural characteristics that can be used as a basis for reasoning about what might be considered appropriate quality attributes that can be measured. These include interfaces and layers, standards, and data interoperability.

When reasoning about architecture, it makes sense to strive for an information-systems environment based on well-defined requirements specification, common data structures, common interface requirements, and well-specified high-level information flows. Systems constructed in accordance with such an architecture are much more likely to be adequately interoperable than those that are not. However, particularly when legacy systems are involved, these commonalities may not exist. In these cases, architectures can supply valuable guidance to isolate gaps and risks relative to interoperability.

\subsection{Interfaces and Layers}

The modular decomposition of systems is typically both horizontal and vertical. Vertical decomposition refers to interfaces between discrete systems within the same layer (e.g., a standard message format used by different applications to exchange information). Horizontal decomposition of functions is known as layering (e.g., the separation of bit transport technologies, transport protocol, and applications). 


\subsubsection{Interfaces}

Systems that perform a variety of functions are normally composed of multiple subsystems or components. Interfaces arise whenever one subsystem or component interacts with another. An architect that is designing and partitioning a system that is intended to interoperate with unspecified existing and future systems must consider the importance of the following:

- Interface design. Well-designed and documented interfaces that permit development programs to be divided into more manageable pieces. This results in faster development because the work of different players can proceed in parallel.

- Encapsulation. This permits modular change in version and implementation technology. By encapsulating the internal details of a system component which may change over time, interfaces allow changes in internal implementation of portions of a system to be transparent to other external systems.

- Reducing interaction. Reducing the complexity of intersystem dependencies facilitates more rapid reconfiguration of systems to meet operational requirements.

\subsubsection{Layers}

Layers facilitate making C4I systems interoperable in the presence of rapidly changing technologies and/or multiple technology choices. Layering makes it possible to design a system of systems that has technology independence, scalability, decentralized operation, appropriate architecture, and supporting standards, security, and flexibility. Layering can also accommodate heterogeneity, accounting, and cost recovery [CSTB 94]. Excellent examples of layering include the use of TCP/IP to decouple communications link technologies from applications that use communications and the use of hypertext transport protocol (HTTP) and hypertext markup language (HTML) to separate presentation from storage and retrieval functions.

Middleware provides an example of the layering principle. It separates the applications from the operating systems on which the applications run [SEI 00], [Bernstein 96]. As outlined in Figure 1, Middleware services are sets of distributed software that exist between the application and the operating system and network services on a system node in the network.

By decreasing the dependence of applications on a particular operating system, middleware increases the ease of moving applications to new computers or systems and decreases dependence on operating systems that might fall out of favor in the commercial marketplace. 


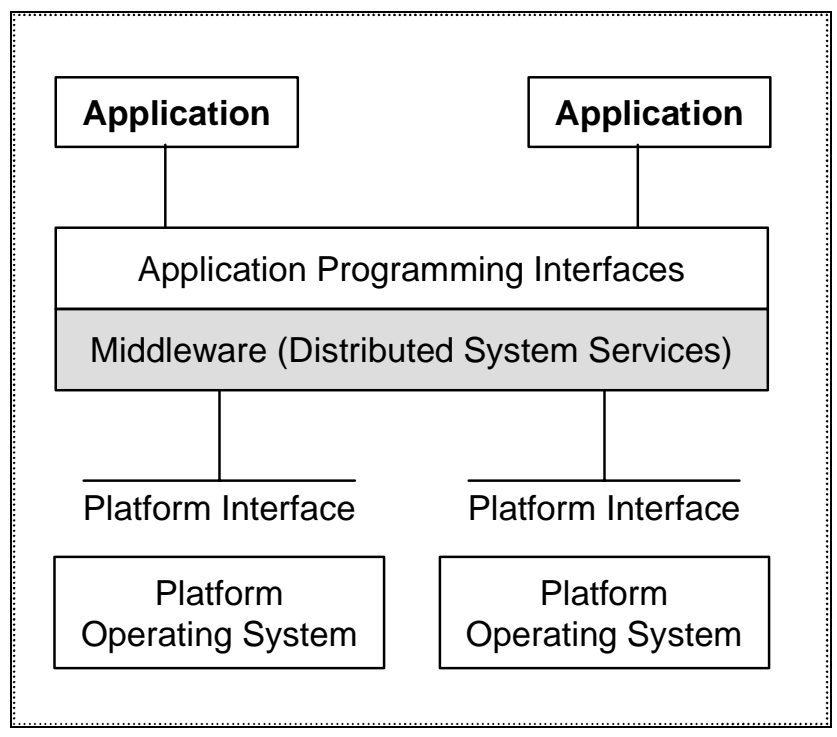

Figure 1: Middleware

The Common Object Request Broker Architecture (CORBA) is one of a number of Middleware platforms for distributed systems development [OMG 98]. Other platforms include Microsoft's .NET and Java 2 Platform, Enterprise Edition. CORBA specifies a system that provides interoperability among objects in a heterogeneous, distributed environment and in a way that is transparent to the programmer. It enables applications to cross the boundaries of different computing machines, operating systems, and programming languages. It specifies how client applications can invoke operations on server objects. Abundant information about CORBA is available from various resources [Cetus 00].

\subsection{Standards}

An essential aspect of architecture is the establishment of technical standards. In general, standards define common elements, such as user interfaces, system interfaces, representations of data, protocols for the exchange of data, and interfaces accessing data or system functions.

Technical standards provide a number of advantages for the systems architect. With regard to interoperability, standards are important because they are accepted by multiple vendors, thereby increasing the likelihood that a collection of systems from diverse sources will be able to interoperate. It has become generally accepted by now that although standards are certainly beneficial, simple adherence to standards is not sufficient to guarantee interoperability [NIMA 98]. Even when there are accepted standards and compliant products, interoperability is facilitated but not assured as there are options within standards and different releases and versions of products.

Finally, it is important to realize that technical standards are, by themselves, necessarily incomplete from the standpoint of a system or component designer. The operational scenarios that a system is expected to support play an integral role. This range of scenarios defines the 
context in which a system is to perform specific desired functions and thus provides a meaningful reference for testing and evaluation.

\subsection{Data Interoperability}

Experience suggests that left to their own devices, the designers of individual systems will often make locally optimal decisions about data definitions and formats [Committee 99]. Data formats resulting from such local decisions may not be compatible when operational requirements dictate that a network of systems be called upon to interoperate. Thus architectural design must provide guidance to developers to minimize the applications-layer incompatibilities that inevitably arise when systems with different purposes must communicate with each other.

Examples of approaches to data interoperability include

- Single data definition for all systems. This approach can be problematic when applied on a large scale to a complex, evolving system or system of systems. The task of agreeing on definitions consumes a great deal of effort and time that might be better used elsewhere. Also, when a single set of definitions is mandated for all applications, definitions are no longer locally optimal, and thus such mandates often encounter substantial resistance in implementation.

- Object orientation. This is a technically promising approach for developing data definitions by encapsulating the internal details of the data [Committee 99].

- Extensible data model. This approach uses an extensible data model and standardized interface. The Simple Network Management Protocol is an example [Cherkaoui 99].

- Extensible Markup Language (XML). This approach requires agreement on the contents and meaning of the XML schema. Thereafter, application data is communicated in XML that conforms to the schema. Like single data definition, obtaining agreement on the schema can be difficult but XML also promises extensibility of data markup.

Legacy systems which have been built around frequently unique data definitions pose a major challenge to interoperability. Industry has developed a number of approaches by which systems not originally designed for interoperability can interoperate to exchange information (including the data "bus" approach, the data dictionary approach, the data translator approach, and the data server approach).

\subsection{DoD Strategy for Addressing Interoperability}

In recognition of the importance of interoperability to realizing its C4I goals (Joint Vision 2010 [Chairman 96] and Joint Vision 2020 [Chairman 00]), the DoD has adopted a joint/defense-wide strategy for promoting interoperability. 
Specifically, there are three major elements that have emerged

1. a triad of interrelated architectures

2. a common defense-wide infrastructure with a common applications platform

3. applications-level efforts to promote interoperability

The three-part architecture is conceptually presented in Table 1 and described by Chatfield [Chatfield 98]. It's important to note that the architectures are not all at the same level of development. DoD architectural development to date has focused on the Joint Technical Architecture (JTA) and it is by far the most mature architecture of the three.

Table 2: $\quad$ Elements of the DoD Architectural Triad [C4ISR 97]

\begin{tabular}{|l|l|}
\hline Part of Triad & Description \\
\hline $\begin{array}{l}\text { Ooint } \\
\text { Architecture }\end{array}$ & $\begin{array}{l}\text { A description (often graphical) of the operational elements, assigned tasks, and } \\
\text { information flows required to support the warfighter. It defines the type of } \\
\text { information exchanged, the frequency of the exchange, and what tasks are } \\
\text { supported by these information exchanges. The operational architecture is a } \\
\text { doctrine-driven representation of C4ISR nodes, roles, processes, } \\
\text { interrelationships, and data/information exchanges. This representation relates } \\
\text { to specific scenarios and joint/combined/coalition mission functions and forms } \\
\text { the basis for realistic process and information flow representation and } \\
\text { prioritization. }\end{array}$ \\
\hline $\begin{array}{l}\text { Joint } \\
\text { Architecture }\end{array}$ & $\begin{array}{l}\text { A description, including graphics, of the systems and interconnections } \\
\text { providing for or supporting a warfighting function. The systems architecture } \\
\text { (view) defines the physical connection, location, and identification of the key } \\
\text { nodes, circuits, networks, warfighting platforms, etc. associated with } \\
\text { information exchange and specifies system performance parameters. The } \\
\text { systems architecture (view) is constructed to satisfy operational architecture } \\
\text { component requirements per the standards defined in the technical architecture. }\end{array}$ \\
\hline $\begin{array}{l}\text { Joint } \\
\text { Architecture }\end{array}$ & $\begin{array}{l}\text { A minimal set of rules governing the arrangement, interaction, and } \\
\text { interdependence of the parts or elements whose purpose is to ensure that a } \\
\text { conformant system satisfies a specific set of requirements. It identifies system } \\
\text { services, interfaces, standards, and their relationships. It provides the } \\
\text { framework upon which engineering specifications can be derived, guiding the } \\
\text { implementation of systems. }\end{array}$ \\
\hline
\end{tabular}




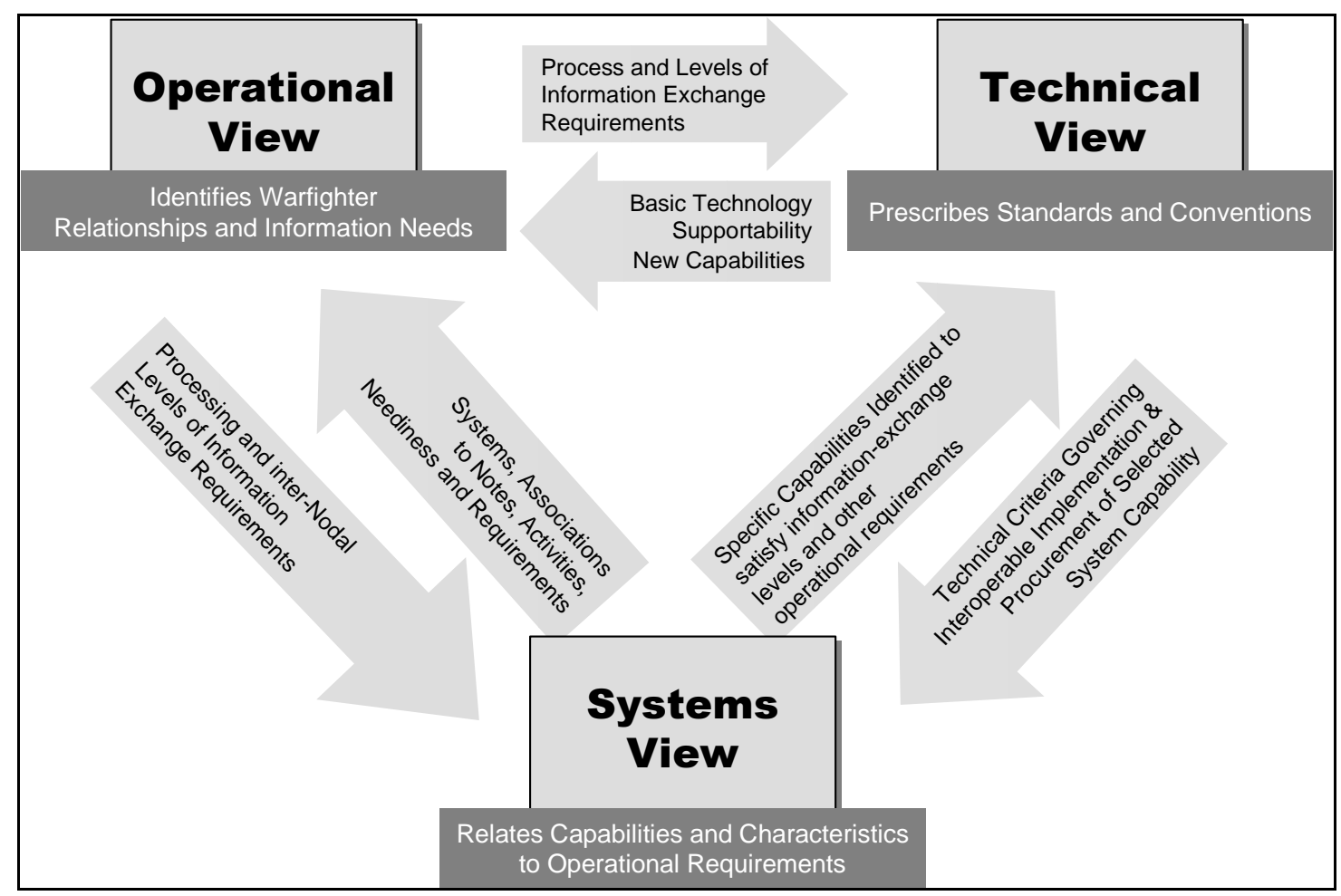

Figure 2: Three Views of an Architecture

The JTA is intended to provide a set of correct and mutually consistent technical standards, application interfaces (APIs), and protocols, along with the decision rules for using them.

The Joint Operational Architecture was originally intended to be a construct covering all military operations. The Information Superiority Campaign Plan of the Joint Chiefs of Staff calls for "the development of a high-level, C4 Joint Operational Architecture that integrates the joint warfare functions, from national level through operational level, into implementations of the JV2010 (Joint Vision 2010) operational concepts" [JCS 00].

An additional piece of the DoD strategy for C4I interoperability is the building of a common, defense-wide information infrastructure called the Defense Information Infrastructure (DII). The DII includes a set of common software called the DII-Common Operating Environment (COE). The DII-COE includes increasingly capable middleware, on top of which service/mission-specific applications can be built. Use of the DII-COE and achieving compliance at certain levels is specified in the JTA.

With regard to data interoperability, the DoD understands the importance of data integration and has launched two major efforts in this area:

1. The Enterprise Data Model Initiative [DoD 91]

2. Shared Data Environment (SHADE) program [DISA 96] 
The Enterprise Data Model Initiative sets forth a DoD process through which standard data definitions in C4I functional areas are developed. They are then subjected to a crossfunctional review process prior to being adopted as DoD standards. The goal of this process is to develop a complete set of standard data elements for DoD applications.

The SHADE program relies on a "bottom-up" approach to enable different C4I systems to share data segments and to use standardized access methods. SHADE has demonstrated some success in enabling legacy systems to interoperate. This program has recently been subsumed by DII-COE. 


\section{Policies Related to Interoperability}

Current systems are increasingly being built to meet explicit requirements for interoperability and flexibility. The DoD's vision of the future-Joint Vision 2010 - is one of information superiority [Chairman 96]. The cornerstone of information superiority is advanced C4I technology and systems which can provide a robust, continuous, common operating picture of the battlespace to all tactical levels of command. ${ }^{2}$ The common operating picture is a central element in a number of initiatives, including

- The Army Digitization Master Plan (Force XXI) [Army 96]

- The Theater Air and Missile Defense Program [TMD Plan 98]

- The Battlefield Awareness and Data Dissemination (BADD) advanced concept technology demonstration (ACTD) [OUSD 99a]

- The "Extending the Littoral Battlespace" (ELB) ACTD [OUSD 99b]

Joint Vision 2010 and Joint Vision 2020 reflect the top-level vision in the DoD of what is possible though the exploitation of technology to solve the interoperability problem [Chairman 96], [Chairman 00]. Each of the services has translated this top-level vision into a service-specific vision [Dept. of Army 96], [Dept. of Air Force 96], [Dept. of Navy 96], [Marine 96]. Each service is exploring the implications of Joint 2010 and Joint 2020, taking steps with experimental studies, wargames, research and development activities, and simulation gaming to develop and test concepts and capabilities that will ensure military preparedness for the coming decades. Additionally, as an extension of individual service experimentation, and in response to congressional pressures, a joint experimentation activity is being established at the U.S. Atlantic Command to address the co-evolution of doctrines, tactics, and new technological capabilities [Committee 99].

The DoD has a number of other initiatives underway that address various aspects of interoperability including

- C4I for the Warrior Concept

- Command, Control Communications, Computers, Intelligence, Surveillance, and Reconnaissance Architecture Framework

- Defense Information Infrastructure Strategy

- Levels of Information Systems Interoperability Initiative

2 The term "common operating picture" refers to a view of the battlespace that is near real-time. 
- Global Information Grid Architecture, including ForceNet, C2 Constellation, and LandWarNet

All of these initiatives are about improving the interoperability of C4I Systems [GAO 98]. 


\section{Information Needs}

Historically, DoD approaches to interoperability have ranged from handling it on a programby-program basis to making limited-scope efforts on a joint, community-wide basis (e.g., the Joint Interoperability of Tactical Command and Control Systems activity to address joint message standards) or a functional community basis (e.g., air defense). In addition, some programs to develop defense-wide infrastructure, dating back to at least the 1960s, have been followed more recently by a few sizable, centrally managed application development programs (e.g., the Global Command and Control System as a replacement for the Worldwide Military Command and Control System [Committee 99]).

However, the responsibility for interoperability is now distributed across the DoD and each of the higher ranks of command has at least one entity charged with responsibility for interoperability issues ${ }^{3}$ as shown in the table below.

Table 3: Interoperability Entities for Agencies and Commands in the DoD

\begin{tabular}{|l|l|}
\hline Agency or Command & Entity Responsible for Interoperability \\
\hline U.S. Atlantic Command & Joint Battle Center \\
\hline Joint Staff & Military Communications and Electronics Board \\
\hline Assistant Secretary of Defense for C3I & Information, Integration, and Interoperability Directorate \\
\hline Defense Information Systems Agency & Joint Interoperability Test Command \\
\hline
\end{tabular}

DoD guidance requires that a system be tested and certified before approval to produce and field it. Depending on the acquisition category and dollar threshold of the program, the approval authority may be one of the following [GAO 98]:

- Undersecretary of Defense (Acquisition and Technology), with advice from the Defense Acquisition Board

- Assistant Secretary of Defense (Command, Control, Communications, and Intelligence), with advice from the Major Automated Information System Review Council

3 The listing of organizations is far from complete. There is a multiplicity of organizations and offices with some responsibility for C4I matters, and organizational structures for C4I (in general) have been rapidly evolving. 
- DoD component head (such as the commander-in-chief of a unified combatant command, the head of a military service, or a DoD agency head)

To ensure interoperability, the Defense Information Systems Agency (DISA), under the direction of the Joint Chiefs of Staff, established the current C4I interoperability certification process in 1992. According to Joint Staff guidance, commanders-in-chief, the four services, and DoD agencies are required to use this process to test and certify existing and newly developed systems for interoperability.

The Joint Staff's Director for C4 Systems (J-6) is assigned primary responsibility for ensuring compliance with the certification requirements. DISA's Joint Interoperability Test Command is the sole certifier of C4I systems. According to Joint Staff guidance, commanders-in-chief (CINCs), the services, and DoD agencies are required to adequately budget for certification testing [GAO 98].

When thinking about these stakeholders, one may note the different perspectives that are working based on the role of the stakeholder. Some entities are operational while others are more focused on planning. Operational units (in the DoD context, CINCs are the warfighting authorities) have a perspective concerned with the capabilities of today's systems (in the short term). Planning units ${ }^{4}$ are concerned with the long-term capabilities of tomorrow's systems.

4 For example, the Office of the Secretary of Defense, Joint Chiefs of Staff, and the service chiefs operate as the policy makers, allocators of resources, and acquirers. 


\section{Measures for Interoperability}

Interoperability is typically assessed by the DoD through non-comprehensive perspectives that are focused, for example, on standards (e.g., the JTA), Common Operating Environment (COE) compliance, data models, or certification criteria, and how individual systems compare against such criteria or standards. It is generally recognized that much more needs to be accomplished in this area [Committee 99].

The popular perception is that interoperability is synonymous with connectivity. However, as previously mentioned, true interoperability is much more than just connectivity. As Robert M. Nutwell, deputy secretary of defense for command, control, communications, and intelligence, surveillance, and reconnaissance systems, explained:

Integration is generally considered to go beyond mere interoperability to involve some degree of functional dependence. For example, a mission planning system might rely on an external intelligence database; an air defense missile system will normally rely on acquisition radar. While interoperable systems can function independently, an integrated system loses significant functionality if the flow of services is interrupted. An integrated family of systems must of necessity be interoperable, but interoperable systems need not be integrated.

Compatibility is something less than interoperability. It means that systems/units do not interfere with each other's functioning. But it does not imply the ability to exchange services. Interoperable systems are by necessity compatible, but the converse is not necessarily true. To realize the power of networking through robust information exchange, we must go beyond compatibility.

In sum, interoperability lies in the middle of an "Integration Continuum" between compatibility and full integration. It is important to distinguish between these fundamentally different concepts of compatibility, interoperability, and integration, since failure to do so sometimes confuses the debate over how to achieve them. While compatibility is clearly a minimum requirement, the degree of interoperability/integration desired in a joint family of systems or units is driven by the underlying operational 
concept, as well as by family of systems (FoS) design and cost/effectiveness tradeoffs. $^{5}$

It is also a function of operational concepts and scenarios, policies, processes, and procedures. For this reason, developing and applying precise measurements in an area as multidimensional and complex as interoperability is difficult. However, the increasing importance of and reliance on C4I support of military operations suggests that the state and health of C4I interoperability be characterized in a more explicit, objective, and measurable way.

To account for the multi-faceted nature of the interoperability domain, we propose four sets of measures that address the following aspects of this challenging problem space:

1. technical compliance measures

2. systems interoperability measures

3. operational interoperability measures

4. organizational and cultural measures

The first three sets of measures are discussed in the context of the Levels of Systems Interoperability (LISI) Model. This evolving model is described in Section 5.1, and Sections 5.1.1 and 5.1.2 describe proposed approaches for addressing the measurement areas listed in the first three numbered items above.

In addition, it is now generally accepted that management must be able to measure what they wish to change. Achieving large-scale cultural change (that is required to bring about interoperability) requires commensurate change in management and the organizational measures of performance. In Section 5.2, a starter set of important management measures for assessing progress related to interoperability is recommended. Section 5.3 describes tradeoff considerations that must be factored in as part of the challenge to promote systems interoperability.

\subsection{Levels of Information Systems Interoperability (LISI)}

The LISI project was initiated in 1993 by MITRE, the C4ISR Integration Task Force, and the ACC Architecture Working Group [C4ISR 98]. LISI is a reference model and process for assessing information systems' interoperability. It is a discipline and a process for defining, measuring, assessing, and certifying the degree of interoperability required or achieved between organizations or systems.

5 Robert M. Nutwell, prepared speech on “Achieving Joint Information Interoperability,” Version 1, April, 2000. 
LISI assesses the level of interoperability attained between systems (not between users). Once system-to-system interoperability issues have been isolated, the ability to address user interoperability issues is vastly improved. For example, LISI concentrates on which user problems are related to functional training needs/shortfalls, differing operational methods and procedures, and difficulties in user-to-computer interactions. Figure 3 (adapted from Hamilton [Hamilton 00]) illustrates this capability.

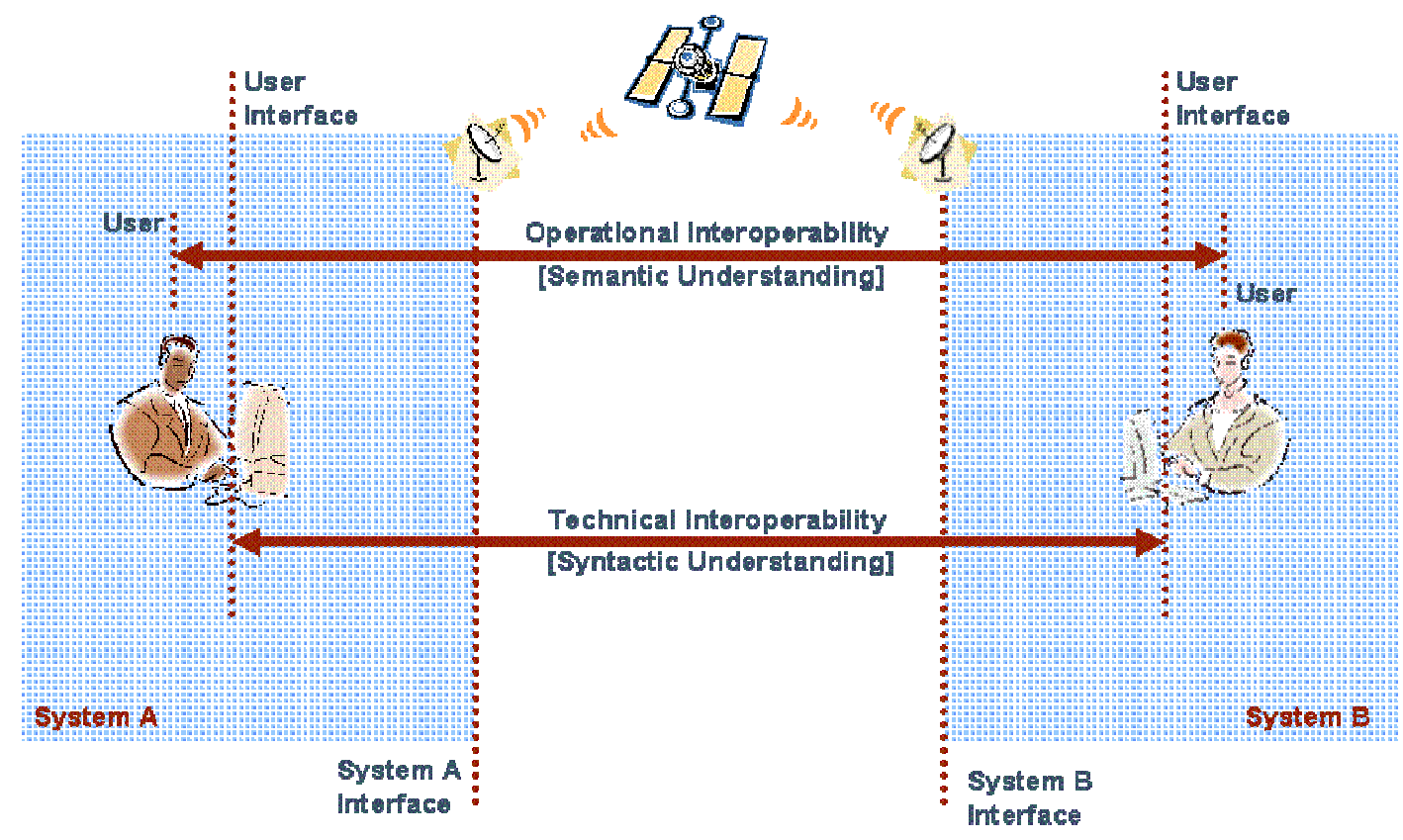

\section{Figure 3: LISI Scope of Analysis}

LISI uses a common frame of reference and measure of performance. LISI is applied throughout the information system life cycle, from requirements analysis through systems development, acquisition, fielding, and subsequent improvement and modification. In this context, LISI

- facilitates a common understanding of interoperability and the suite of capabilities enabling each logical level of system-to-system interaction

- provides an interoperability maturity model and associated requisite capabilities as the basis for making comparisons between heterogeneous systems and maturing individual systems

- provides a methodology for assessing and improving interoperability by guiding requirements and architecture analysis, systems development, acquisition, fielding, and technology insertion

Table 3 presents an overview of the LISI Interoperability Maturity Model. This model identifies the stages through which a system should logically progress to improve its capabilities to interoperate. LISI considers five increasing levels of sophistication regarding system interaction and the ability of the system to exchange and share information and 
services. Each higher level represents a demonstrable increase in capabilities over the previous level of system-to-system iteration.

\section{Table 4: $\quad$ Overview of the LISI Interoperability Maturity Model}

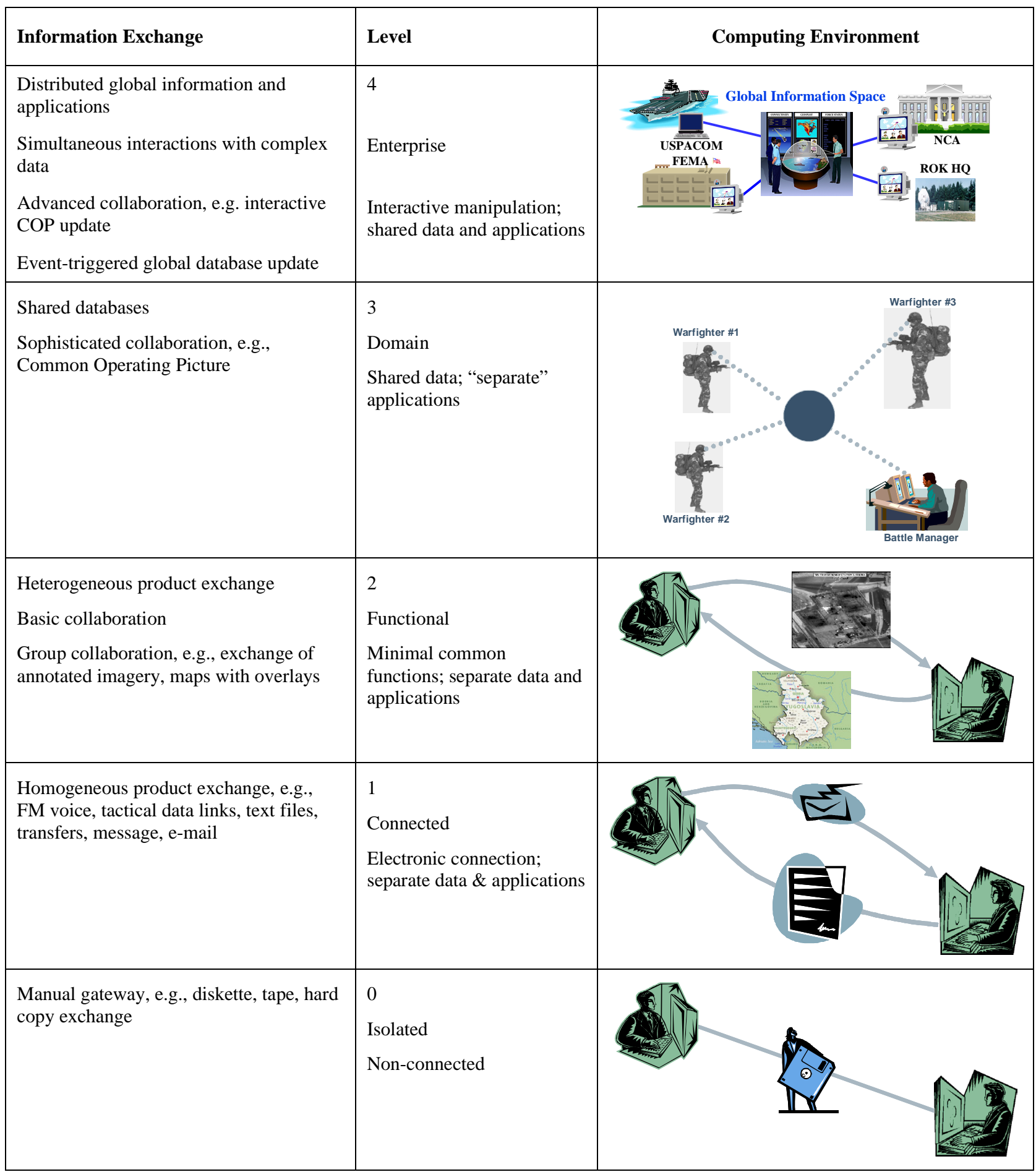


A critical element of interoperability assurance is a clear prescription of the common suite of requisite capabilities that must be inherent in all information systems that desire to interoperate at a selected level of sophistication. Each level's prescription of capabilities must cover all four enabling attributes of interoperability, as shown in the table below.

\section{Table 5: PAID Attributes}

\begin{tabular}{|l|l|l|}
\hline P & Procedures & $\begin{array}{l}\text { Policies and procedures govern a system's development through established standards and } \\
\text { the procedures and processes which influence system integration and functional } \\
\text { operational requirements }\end{array}$ \\
\hline $\mathbf{A}$ & Applications & $\begin{array}{l}\text { The functions a system is intended to perform. These functions reside most often in the } \\
\text { form of user-based application programs which perform or support a specific set of } \\
\text { processes or procedures. }\end{array}$ \\
\hline I & Infrastructure & $\begin{array}{l}\text { The infrastructure required to support the systems operations. Contains four sub- } \\
\text { components which are also defined in terms of increasing levels of sophistication. }\end{array}$ \\
\hline D & Data & $\begin{array}{l}\text { The data and information structures used to support both the functional applications and } \\
\text { system infrastructure. }\end{array}$ \\
\hline
\end{tabular}

In addition, for each prescribed capability, system developers need to know what implementation options are available, and which options conform to prevailing DoD criteria. The LISI Capabilities Model and its associated Implementation Options Tables identify the full suite of capabilities and available technical implementations for attaining each level of interoperability. Table 5 summarizes the LISI Reference Model and shows the relationship of the PAID attributes. 
Table 6: LISI Reference Mode

\begin{tabular}{|c|c|c|c|c|c|c|}
\hline \multirow[b]{2}{*}{ Description } & \multirow[b]{2}{*}{ Computing Environment } & \multirow[b]{2}{*}{ Level } & \multicolumn{4}{|c|}{ Interoperability Attributes } \\
\hline & & & Procedures & Application & Infrastructure & Data \\
\hline Enterprise & Universal & 4 & $\begin{array}{l}\text { Enterprise } \\
\text { Level }\end{array}$ & Interactive & $\begin{array}{l}\text { Multiple } \\
\text { Dimensional } \\
\text { Topologies }\end{array}$ & $\begin{array}{l}\text { Enterprise } \\
\text { Model }\end{array}$ \\
\hline Domain & Integrated & 3 & Domain Level & Groupware & $\begin{array}{l}\text { Worldwide } \\
\text { Network }\end{array}$ & $\begin{array}{l}\text { Domain } \\
\text { Model }\end{array}$ \\
\hline Functional & Distributed & 2 & Program Level & $\begin{array}{l}\text { Desktop } \\
\text { Automation }\end{array}$ & $\begin{array}{l}\text { Local } \\
\text { Networks }\end{array}$ & $\begin{array}{l}\text { Program } \\
\text { Model }\end{array}$ \\
\hline Connected & Peer-to-Peer & 1 & $\begin{array}{l}\text { Local/Site } \\
\text { Level }\end{array}$ & $\begin{array}{l}\text { Standard } \\
\text { System } \\
\text { Drivers }\end{array}$ & $\begin{array}{l}\text { Simple } \\
\text { Connection }\end{array}$ & Local \\
\hline Isolated & Manual & 0 & Access Control & N/A & Independent & Private \\
\hline
\end{tabular}

Table 6 (adapted from a 1998 report [C4ISR 98]) presents a general overview of the major elements that comprise LISI. LISI provides an assessment process for determining the interoperability maturity level or "measure" of a given system or system pair. (Note in Table 6 that Interoperability Metrics is included as one of the LISI assessment products.) 
Table 7: $\quad$ Overview of the LISI Elements

\begin{tabular}{|c|c|c|}
\hline & LISI Element & Description \\
\hline \multirow{4}{*}{ 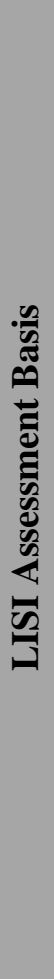 } & $\begin{array}{l}\text { Interoperability Maturity } \\
\text { Model }\end{array}$ & $\begin{array}{l}\text { Defines the five levels of interoperability expressed within LISI. } \\
\text { The LISI interoperability Maturity Model describes the increasing } \\
\text { sophistication of system-to-system interactions as one moves from } \\
\text { one level to the next. }\end{array}$ \\
\hline & Reference Model & $\begin{array}{l}\text { Characterizes the five levels of interoperability in terms of four } \\
\text { comprehensive, integrated attributes: procedures, applications, } \\
\text { infrastructure, and data (PAID). At any particular level of } \\
\text { interoperability, a set of specific capabilities must be present for } \\
\text { each attribute in order to achieve the degree of interoperability } \\
\text { maturity defined by that level. }\end{array}$ \\
\hline & Capabilities Model & $\begin{array}{l}\text { Defines the specific capability thresholds (i.e., capability suites } \\
\text { across PAID) required for attaining each level of interoperability. } \\
\text { This model provides the level of detail needed to determine systems } \\
\text { interoperability profiles and measures, and provides the basis for } \\
\text { conducting LISI assessments. }\end{array}$ \\
\hline & $\begin{array}{l}\text { Implementation Options } \\
\text { Tables }\end{array}$ & $\begin{array}{l}\text { Captures the full range of possible implementation choices that are } \\
\text { available to developers for implementing each of the capabilities } \\
\text { identified in the Capabilities Model. }\end{array}$ \\
\hline \multirow{4}{*}{ 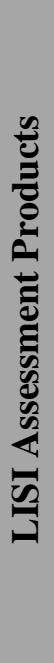 } & Interoperability Profiles & $\begin{array}{l}\text { The interoperability profile for a particular system is produced as a } \\
\text { result of completing the LISI questionnaire. This profile contains } \\
\text { the specific implementation choices made by a particular developer } \\
\text { regarding a specific system or application. }\end{array}$ \\
\hline & Interoperability Metrics & $\begin{array}{l}\text { Calculated by applying the Capabilities Model to the data collected } \\
\text { from the questionnaire. Through this mapping, a profile emerges } \\
\text { which depicts the organized set of capabilities exhibited by a } \\
\text { system in terms of the LISI levels. The result is a "measure" which } \\
\text { captures the level of interoperability that a system possesses. }\end{array}$ \\
\hline & Comparison Tables & \multirow{2}{*}{$\begin{array}{l}\text { These LISI products are developed by comparing and assessing the } \\
\text { interoperability profiles and measures for a given suite of systems. }\end{array}$} \\
\hline & Architecture Products & \\
\hline
\end{tabular}




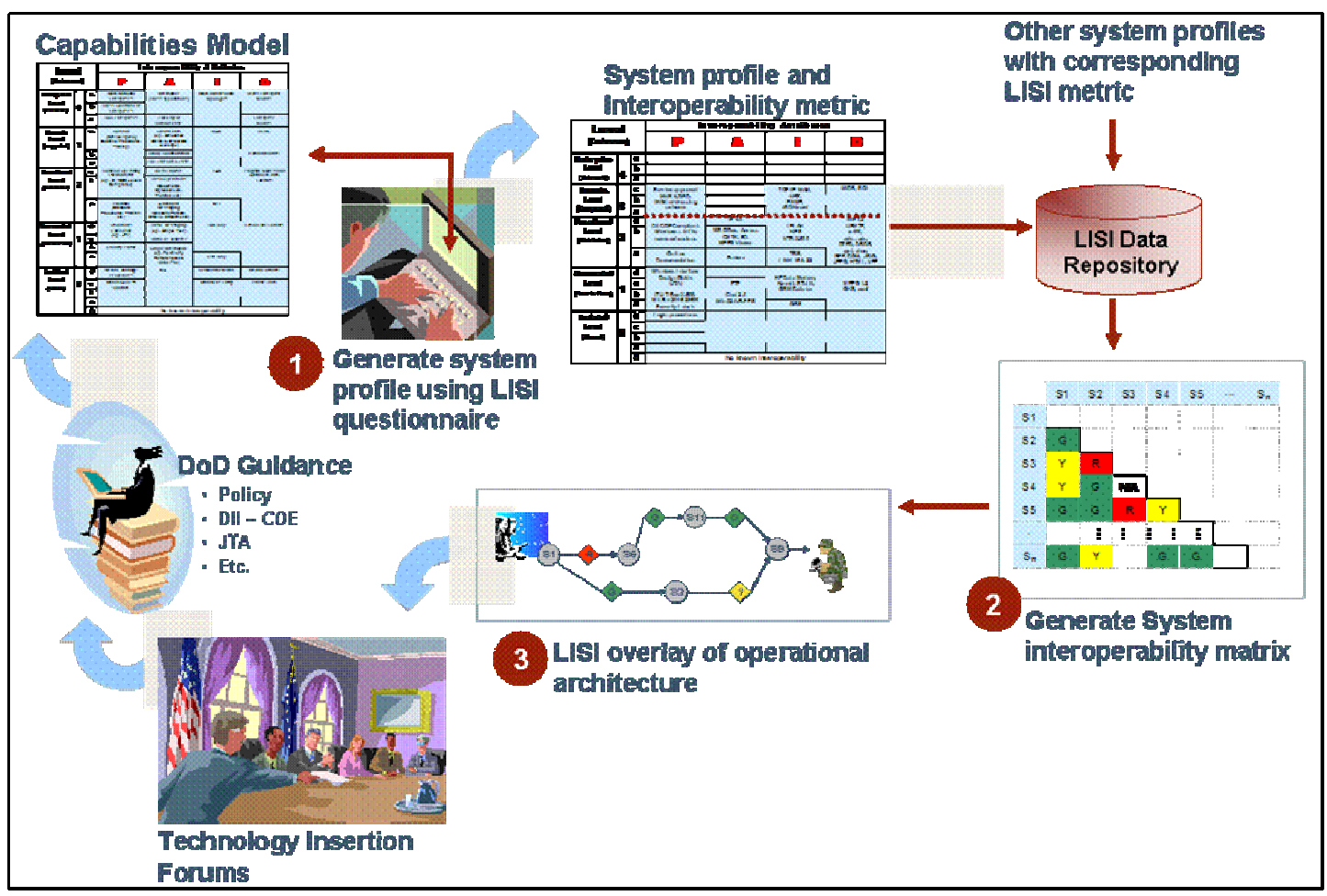

Figure 4: The LISI Interoperability Assessment Process

Using the LISI approach, interoperability measures could be deduced using a scorecard method, as shown in Figure 4 (adapted from a 1998 report [C4ISR 98]). In the absence of precise measures and recognizing the multidimensionality of interoperability, it is reasonable to use scorecard techniques based on human judgment to capture how well a unit (or the DoD as a whole) is doing with respect to

- technical compliance

- $\quad$ system-to-system interactions

- operational mission effectiveness

\subsubsection{Measuring Technical Compliance}

The technical view of an architecture focuses on the criteria governing the implementation of specific system capabilities or attributes. From an assessment perspective, the concern is whether a given system's implementation complies with the applicable standards and guidelines. Therefore, a technical scorecard could be viewed as a list of systems with ratings (pass/marginal/fail) of compliance with the relevant standards and guidelines.

The purpose of the LISI measure is to capture the essence of potential interactions available between systems, as registered through the implementation choices made by developers. The 
measure is therefore a direct reflection of the comparison of interoperability provided between systems.

The LISI measure provides a shorthand definition of the particular form of interoperability as expressed in the LISI maturity model. The measure comes in various types based on the nature, purpose, and approach to performing and displaying the results of the comparisons. An example of the various options for describing LISI measures is shown in Table 7 (adapted from a 1998 report [C4ISR 98]).

Table 8: LISI Interoperability Measures

\begin{tabular}{|l|l|c|}
\hline \multirow{4}{*}{ Metric type } & Generic & Code \\
\cline { 2 - 3 } & Expected & $\mathrm{G}$ \\
\cline { 2 - 3 } & Specific & $\mathrm{E}$ \\
\hline \multirow{2}{*}{ Level } & Enterprise & $\mathrm{S}$ \\
\cline { 2 - 3 } & Domain & 4 \\
\cline { 2 - 3 } & Functional & 3 \\
\hline & Connected & 1 \\
\hline & Isolated & 0 \\
\hline \multirow{2}{*}{ Sublevel } & $\begin{array}{l}\text { Varies by levels; defined } \\
\text { as "a" through "z" }\end{array}$ & $\mathrm{a}-\mathrm{z}$ \\
\hline
\end{tabular}

The main distinction among the three types of LISI measures is the comparison of a single system against the capabilities model (generic) and the two different cases where two or more systems are compared to each other (expected and specific). The expected level of interoperability between two systems is simply the lesser of the two systems' generic levels, or the level at which one would expect the two systems to interoperate. The specific level of interoperability is the calculated measure between two systems as a result of comparing the specific implementation choices that each system has made regarding the registered PAID capabilities. The specific level may be different than the expected level based on the added use of the LISI Options Tables and the consideration of the technical implementation criteria. These are more formally defined elsewhere [C4ISR 98].

As an example, ${ }^{6}$ using the measures in Table 7, consider that a system assessment was conducted and the LISI measure obtained was "G2c." Such a rating of the inherent characteristics of this system would mean the system or application has a generic level of "2c." Therefore

- It complies with JTA and DII-COE.

- It can operate on a LAN.

- Its environment is built within a GUI.

6 This is adapted from the 1998 report [C4ISR 98]. 
- It supports common office functions.

- Its database information is compliant with a particular functional program.

The LISI measure obtained from these comparisons can be represented in several formats, including those described in Table 8. Figure 5 shows the example populated interoperability profile for this system. In this example, the system's generic interoperability level is $2 c$, the highest level at which a capability is implemented for each of the PAID attributes.

Table 9: Possible Formats for a LISI Measure

\begin{tabular}{|l|l|l|}
\hline Format & Description & Examples \\
\hline Summary LISI measure & Only the major level and/or sublevel is shown. & G2, E3, G2b, S3C \\
\hline Detailed LISI measure & $\begin{array}{l}\text { Individual values of PAID are each portrayed as separate } \\
\text { components within the measure }\end{array}$ & G2(P3A2I3D2) \\
\hline
\end{tabular}

\begin{tabular}{|c|c|c|c|c|c|c|c|}
\hline - & & & $\mathrm{In}$ & eroperabil & y Attribut & & \\
\hline (Environm & ent) & & $P$ & & & D & \\
\hline Enterprise & & C & & & & & \\
\hline Level & 4 & $\mathrm{~b}$ & & & & & \\
\hline (Universal) & & $\mathrm{a}$ & & & & & \\
\hline Domain & & c & Service-approved & & TCP/IP WAN, & MIDB, SQL & \\
\hline $\begin{array}{c}\text { Level } \\
\text { (Integrated) }\end{array}$ & 3 & $\mathrm{~b}$ & $\begin{array}{c}\text { WAN addressing } \\
\text { scheme }\end{array}$ & & $\begin{array}{l}\text { NFS, } \\
\text { SNMP, } \\
\text { ISDN card }\end{array}$ & & \\
\hline & & $\mathrm{a}$ & & & & & Level 2C \\
\hline Functional & & $\mathrm{C}$ & DII cof Comnliant & & ID & & \\
\hline $\begin{array}{c}\text { Level } \\
\text { (Distributed) }\end{array}$ & 2 & $b$ & $\begin{array}{l}\text { Windows-std file } \\
\text { name extensions } \\
\end{array}$ & $\begin{array}{c}\text { MS Office, Access } \\
\text { CMTK, 5D, } \\
\text { MPEG Viewer }\end{array}$ & $\begin{array}{c}\text { NES } \\
\text { NTP.X.500 }\end{array}$ & $\begin{array}{c}\text { x.400, } \\
\text {.wks, . xIs, } \\
\text { DTED, DBDB, }\end{array}$ & \\
\hline & & $\mathrm{a}$ & $\begin{array}{c}\text { On line } \\
\text { Documentation }\end{array}$ & Eudora & $\begin{array}{c}\text { TBS, } \\
\text { LINK } 16 \& 22\end{array}$ & $\begin{array}{c}\text {.ppt, .doc, } \\
\text { RPF, CGM, JBIG, } \\
\text { JPEG, HTML, VPF }\end{array}$ & \\
\hline Connected & & $\mathrm{d}$ & $\begin{array}{l}\text { Windows Interface } \\
\text { Design Guide }\end{array}$ & & HF Data Modem, & & \\
\hline Level & 1 & $\mathrm{C}$ & (JTA) & FTP & $\begin{array}{l}\text { Kermit, STU III, } \\
\text { GSM Cellular }\end{array}$ & $\begin{array}{l}\text { MPEG } 1.2 \\
\text { GKS. wmf }\end{array}$ & \\
\hline & & $\mathrm{b}$ & ITU-T Rec X.509. & Chat 2.0 & & & \\
\hline & & $\mathrm{a}$ & Security Labels & & GBS & & \\
\hline Isolated & & $d$ & Login procedures & & & & \\
\hline Level & 0 & $\mathrm{C}$ & & & & & \\
\hline (Manual) & & $\mathrm{b}$ & & & & & \\
\hline & & $\mathrm{a}$ & & & & & \\
\hline & & 0 & & No known int & roperability & & \\
\hline
\end{tabular}

\section{Figure 5: Example Populated Interoperability Profile for 2c System}

In addition to the LISI measure, others have defined architectural attributes that could serve as indicators of interoperability. These appear in Appendix A. 


\subsubsection{Potential Systems Interoperability Scorecard}

The systems view of an architecture focuses on the information and communications systems that are brought to bear to support the information flows required to accomplish operational missions. The Systems Interoperability Scorecard attempts to measure the degree to which the various system pairs can effectively interoperate in context to meet these information flow requirements.

A potential interoperability matrix can be generated for a group of systems based on the generic interoperability level of each system and the specific interoperability level for each system pair within the group. Figure 6 (adapted from Committee [Committee 99]) presents an example. In this view, a scorecard used to measure interoperability from a systems perspective would focus on the ability of the systems in each pair to interact with one another. The scorecard could be viewed as a matrix with the systems represented in both the rows and columns and entries indicating system-to-system interoperability as inadequate (red), marginal (yellow), or adequate (green).

\begin{tabular}{|l|c|c|c|c|c|c|c|}
\hline & S1 & S2 & S3 & S4 & S5 & $\ldots$ & Sn $_{n}$ \\
\hline S1 & & & & & & & \\
\hline S2 & G & & & & & & \\
\hline S3 & Y & R & & & & & \\
\hline S4 & Y & G & N/ & & & & \\
\hline S5 & G & G & R & Y & & & \\
\hline . & ! & $\vdots$ & $\vdots$ & ! & $\vdots$ & & \\
\hline S & G & Y & & G & G & & \\
\hline
\end{tabular}

Figure 6: Example Systems Operability Scorecard

\subsubsection{Measuring Operational Interoperability}

The operational view of an architecture addresses particular mission slices, such as targeting, close air support, and force sustainment of a broader operational setting. Within each slice, the view could capture the players involved and their interactions, their functions, decisions, actions, and the flows of information postulated to support their particular roles in achieving overall mission effectiveness.

The review of a system's Operational Requirements Document will determine the existence of system interoperability requirements. (Note: system interoperability is discussed in the next section.) The first step in measuring compliance of these requirements is to trace the requirements through the system functions. This may be accomplished by the development of operational threads (system node connectivity or link/node diagrams) or paths between the 
systems. The threads are identified, traced, and developed in order to measure and quantify system interoperability [Leite 98].

A scorecard used to assess interoperability from an operational architecture perspective would focus on the ability to satisfy specific node-to-node information flow requirements (that describe the nature of the information and services needed, its directional flow, and the constraints and demands imposed by the operational environment. This is illustrated in Figure 7 (adapted from Committee [Committee 99]). The assessed degree to which each flow requirement is met can be scored using green/yellow/red ratings. These measures are often derived from lessons learned through crises or exercises including observed events and anecdotal feedback [Committee 99].

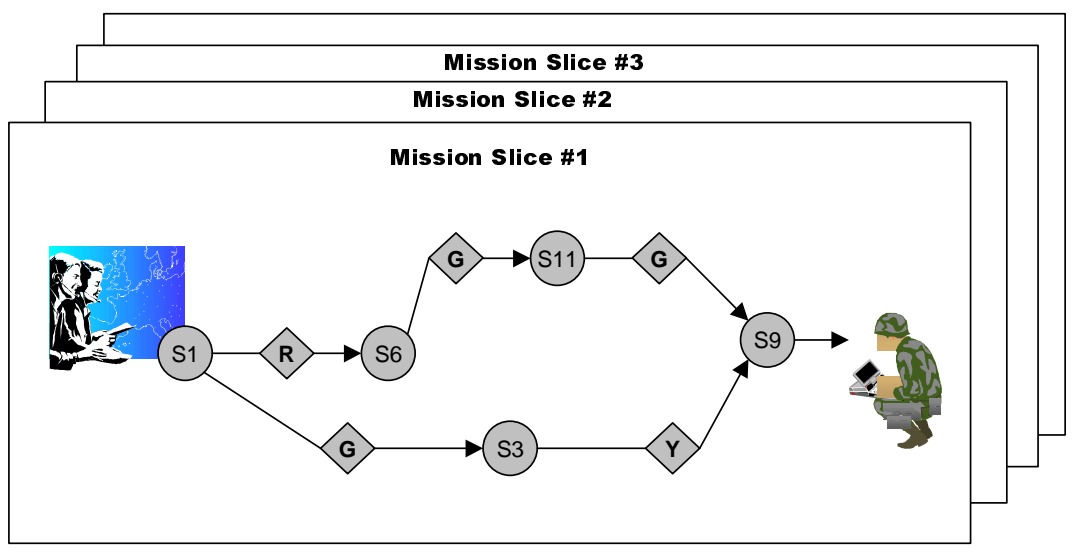

\section{Figure 7: Example of an Operational Interoperability Scorecard}

At this level it is possible to estimate and measure important quality attributes associated with interoperability. Leite has defined these relationships and they are summarized in Table 9 [Leite 98]. The mathematical relationships for each of these measures are defined in Appendix A. 
Table 10: Quality Attributes Associated with Interoperability

\begin{tabular}{|c|c|}
\hline Attribute Measure & Description \\
\hline Connectivity & $\begin{array}{l}\text { Connectivity can be directly measured by counting the number of messages } \\
\text { initiated by all participating units and the number of messages received for the } \\
\text { network or data link. To the extent that the link is in continuous operation, the } \\
\text { connectivity sampled in this manner is representative of network connectivity. } \\
\text { If the network is operated intermittently, then the sample must be carefully } \\
\text { selected and tested to ensure that the required confidence level is attained. }\end{array}$ \\
\hline Capacity & $\begin{array}{l}\text { The capacity of a system is the rate at which data may be passed over time. } \\
\text { Given its operating parameters, a maximum data rate can be calculated for any } \\
\text { system or group of systems. }\end{array}$ \\
\hline System overload & $\begin{array}{l}\text { A system overload occurs when more data must be exchanged than the system } \\
\text { is able to transmit. Typically, the overload is placed in a queue and is then } \\
\text { transmitted when capacity is available. Therefore, the measure of system } \\
\text { overload is the sum of the messages remaining in queues after their assigned } \\
\text { transmission period for all system nodes. }\end{array}$ \\
\hline Underutilization & $\begin{array}{l}\text { Underutilization occurs when the system data rate/message load is less than its } \\
\text { full capacity but messages are waiting in queues to be transmitted. This occurs } \\
\text { when the item slot or transmission allocation to selected nodes is less than that } \\
\text { required to clear the queue by the end of a transmission period. Similarly other } \\
\text { nodes do not use all of their allocated time. }\end{array}$ \\
\hline Undercapacity & $\begin{array}{l}\text { Undercapacity occurs when messages remain in queues and the system data } \\
\text { rate is at the maximum. }\end{array}$ \\
\hline Data latency & $\begin{array}{l}\text { Data latency is the elapsed time from the time of the event to the time of } \\
\text { receipt by the user (tactical data processor). For analytical purposes, the } \\
\text { latency is often divided into smaller segments. Several common time periods } \\
\text { are the following: } \\
\text { - time of event to time of observation } \\
\text { - time of observation to completion of processing } \\
\text { processor } \\
\text { This division is useful in situations involving a remote sensor and intermediate } \\
\text { processing to reduce the data to a usable form (track message) prior to passing } \\
\text { the data to the user. }\end{array}$ \\
\hline $\begin{array}{l}\text { Information interpretation } \\
\text { and utilization }\end{array}$ & $\begin{array}{l}\text { Having passed the data and correctly interpreted it, the next step would be to } \\
\text { verify that the proper action is taken. Verification of the action taken involves } \\
\text { a review of the logic associated with each option that is possible in response to } \\
\text { a message or operator action. These deal, of course, with questions of } \\
\text { interoperability and not with the difficult, higher level topic of measuring } \\
\text { mission effectiveness. }\end{array}$ \\
\hline
\end{tabular}




\subsection{Management Measures Associated With Interoperability}

The magnitude of the technology-driven transformation required to achieve interoperability points to the enormity of the institutional challenges associated with the transformation. The Committee to Review DoD C4I Plans and Programs found that "achieving C4I interoperability is more a matter of organizational commitment and management ${ }^{7}$ than one of technology" [Committee 99].

Adequate C4I interoperability is inherently a distributed, horizontal challenge that must be addressed in a largely vertical world. Enabling fast and effective responses to this challenge requires that interoperability be built into the force structure across service and unit boundaries. This means that there must be incentives for investments and actions across organizational boundaries. Crossing these boundaries is particularly important to the development and fielding of systems that support joint operations. The DoD must search for practical ways to reward interoperability.

Measures are important to senior decision makers. The Information Technology Reform Act (ITMRA) of 1996 (Public Law 104-106), also known as the Clinger-Cohen Act, requires the Federal government to develop

“... a process and procedure for establishing goals for improving the efficiency and effectiveness of government agencies operations and the ability to deliver goods and services to the public using Information Technology. The goals must be measurable." ${ }^{8}$

Achieving large-scale cultural change in an organization to achieve C4I interoperability requires commensurate change in management and the organizational measures. In large organizations, the behavior of personnel is strongly influenced by the measures that management uses to assess performance, whether those measures are part of a formal assessment or are more perceived than formal. People are keenly aware of what matters in terms of rewards, promotion, and credit and they behave in a manner consistent with their perceptions. Good management measures help to drive organizational behavior that supports areas of operational significance. In general, management measures focus on organizational performance or characteristics and are used by senior management to assess the effectiveness of the organization and its leadership.

The Committee to Review DoD C4I Plans and Programs has identified the following list of possible management measures to promote interoperability across the board:

- Number of C4I systems that conform to the Joint Technical Architecture

7 This includes allocation of resources, attention to detail, and continuing diligence.

8 Please see http://wwwoirm.nih.gov/policy/itmra.html for more information. 
- Number of individuals trained in the use of specific C4I systems

- Number of C4I systems "certified" to be interoperable

- Time or personnel required to develop time-phased force and deployment data or an airtasking order

- Time needed to stand up a tactical network for a joint task force

\subsection{Summary of Recommended Measures}

The Practical Software and Systems Measurement (PSM) approach is based on actual measurement experience on government and industry projects [PSM 98]. It represents a collection of best practices used by measurement professionals within the software and systems acquisition and engineering communities. The PSM selection and specification approach is based on the direct relationship between project issues, information needs, and the measures that support the required information. To implement this approach, PSM maps Common Issue Areas to related Measurement Categories, and then to measures in each category. The following table summarizes recommended measures that have been organized into the PSM Issue-Category-Measure (ICM) structure.

Table 11: Summary of Recommended Measures

\begin{tabular}{|c|c|c|c|}
\hline Specific Issues & Common Issue Area & Measurement Category & Recommended Measure \\
\hline $\begin{array}{l}\text { Compliance } \\
\text { With Standards }\end{array}$ & Technical Adequacy & Technical Performance & LISI generic level of interoperability \\
\hline $\begin{array}{l}\text { Systems } \\
\text { Interoperability }\end{array}$ & Technical Adequacy & Technical Performance & LISI expected level of interoperability \\
\hline $\begin{array}{l}\text { Operational } \\
\text { Interoperability }\end{array}$ & Technical Adequacy & Technical Performance & LISI specific level of interoperability \\
\hline $\begin{array}{l}\text { Operational } \\
\text { Interoperability }\end{array}$ & Technical Adequacy & Technical Performance & Connectivity $^{\dagger}$ \\
\hline $\begin{array}{l}\text { Operational } \\
\text { Interoperability }\end{array}$ & Technical Adequacy & Technical Performance & Capacity $^{\dagger}$ \\
\hline $\begin{array}{l}\text { Operational } \\
\text { Interoperability }\end{array}$ & Technical Adequacy & Technical Performance & System Overload ${ }^{\dagger}$ \\
\hline $\begin{array}{l}\text { Operational } \\
\text { Interoperability }\end{array}$ & Technical Adequacy & Technical Performance & Underutilization $^{\dagger}$ \\
\hline $\begin{array}{l}\text { Operational } \\
\text { Interoperability }\end{array}$ & Technical Adequacy & Technical Performance & Undercapacity $^{\dagger}$ \\
\hline $\begin{array}{l}\text { Operational } \\
\text { Interoperability }\end{array}$ & Technical Adequacy & Technical Performance & Data latency $y^{\dagger}$ \\
\hline $\begin{array}{l}\text { Operational } \\
\text { Interoperability }\end{array}$ & Technical Adequacy & Technical Performance & $\begin{array}{l}\text { Information interpretation and } \\
\text { utilization }\end{array}$ \\
\hline
\end{tabular}

$\dagger$ For a formal definition of this measure, refer to Appendix D. 


\begin{tabular}{|l|l|l|l|}
\hline $\begin{array}{l}\text { Management } \\
\text { Commitment }\end{array}$ & Schedule and Progress & Milestone Performance & $\begin{array}{l}\text { Number of C4I systems that conform } \\
\text { to the Joint Technical Architecture }\end{array}$ \\
\hline $\begin{array}{l}\text { Management } \\
\text { Commitment }\end{array}$ & Schedule and Progress & Milestone Performance & $\begin{array}{l}\text { Number of C4I systems "certified" to } \\
\text { be interoperable }\end{array}$ \\
\hline $\begin{array}{l}\text { Management } \\
\text { Commitment }\end{array}$ & $\begin{array}{l}\text { Development } \\
\text { Performance }\end{array}$ & Productivity & $\begin{array}{l}\text { Time needed to stand up a tactical } \\
\text { network for a joint task force }\end{array}$ \\
\hline $\begin{array}{l}\text { Management } \\
\text { Commitment }\end{array}$ & $\begin{array}{l}\text { Development } \\
\text { Performance }\end{array}$ & Productivity & $\begin{array}{l}\text { Time or personnel required to develop } \\
\text { time-phased force and deployment data } \\
\text { or an air-tasking order }\end{array}$ \\
\hline $\begin{array}{l}\text { Management } \\
\text { Commitment }\end{array}$ & Resources and Cost & Personnel & $\begin{array}{l}\text { Number of individuals trained in the } \\
\text { use of specific C4I systems }\end{array}$ \\
\hline
\end{tabular}

\subsection{Tradeoff Analysis}

Although interoperability is a critical enabler for military operations, it must be recognized as just one of several technical attributes of any system of systems. Military commanders need many things from their C4I systems besides interoperability, and tradeoffs among these needs are often required. Other attributes will sometimes be in competition with interoperability and with each other. In thinking about overall system functionality or performance, security requirements such as confidentiality, authentication, non-repudiation, integrity, and system availability must be considered together with interoperability. An appropriate balance must be sought. For example, there are tradeoffs between security and interoperability. Interoperability can promote an attacker's access to diverse systems, thus facilitating the rapid spread of attacks.

\subsection{Recommendations}

The following recommendations are made for further exploration:

- Investigate current efforts to track interoperability on a comprehensive basis. ${ }^{9}$ This includes investigating the maturity and use of LISI as a framework to assess interoperability. ${ }^{10}$

- Analyze results from well-instrumented simulations and exercises to evaluate tradeoffs between interoperability and other fundamental attributes of C4I systems, including security, availability, flexibility, survivability, and performance.

- Examine scenario-based assessment and architectural-style-based assessment as a way to better understand interoperability measures and the tradeoffs involved between other

9 The Committee to Review DoD C4I Plans and Programs determined that despite laudable case-by-case efforts to track interoperability, there is today no method for tracking interoperability on a comprehensive or systematic basis [Committee 99].

10 CJCSI 6212.OIC, November 20, 2003, Mandate LISI assessments for all ICIDS Acquisition Category programs referenced in CJCSI 3170.012, CJCSM3170.OIM and all not-ACAT and fielded systems. 
quality attributes of a system. ${ }^{11}$ Investigate appropriate interoperability measures using the Architecture Tradeoff Analysis Method (ATAM) [Kazman 00].

- Explore the use of multivariate analysis to take into account the likely interdependence of various interoperability measures and competing system quality attributes.

11 Investigations in this area would be based on foundational work described by Bass et al., Barbacci et al., and Taylor [Bass 98], [Barbacci 95], [Taylor 00]. 


\section{Appendix A Some Historical Definitions of Interoperability}

A number of reports and technical papers have defined interoperability:

- "The effort required to couple one system with another" [McCall 80].

- "The ability of systems, units, or forces to provide services to and accept services from other systems, units, or forces and to use the services so exchanged to enable them to operate effectively together" [DoDD 77].

- "The ability of one services' system to receive and process intelligible information of mutual interest transmitted by another service's system" [JINTACCS 74].

- "The ability of one system to receive and process intelligible information of mutual interest transmitted by another system" [Eldridge 78].

- "The ability of two or more systems or components to exchange information and to use the information that has been exchanged" [IEEE 90].

There are problems with McCall's definition. Here, "coupling" includes linking two programs to interoperate on a single computer or linking programs on separate computers to interoperate. The quality factor, interoperability, is therefore important when:

- retrofitting two or more previously developed systems into one system

- developing new systems independently that will interoperate with each other

- developing a system with the expectation that it will eventually interoperate with an, as yet, undefined future system

The definition, taken literally, includes only the connectivity and compatibility issues of interoperability, implying only equipment-level considerations. But hardware compatibility does not assure interoperability. For example, two persons using exactly the same transmitters on the same frequency may not be able to interoperate, particularly if one person speaks only English, the other speaks only Arabic. Interoperability is achieved when both persons can transmit and receive information of mutual use and understandability.

Eldridge's definition of interoperability is also unsatisfactory because it stresses standardization. The emphasis on standardization of hardware and software overlooks the content of the messages and the differing operational requirements that affect interoperability.

The JINTACCS and DoDD 2010.6 [DoDD 77] definitions are preferable. These definitions seem to most accurately define the ultimate meaning of interoperability—as a broad and complex subject rather than a binary attribute of systems. 
More recently, the Joint Chiefs of Staff Publication 1-02 [DoD 98] defines interoperability in a way that acknowledges the technical and operational components that contribute to a more meaningful interpretation. 


\section{Appendix B Testing Interoperability}

C4I interoperability depends on architecture and the resultant requirements specification.

Testing compares actual performance with requirements. Ensuring that the architecture and requirements are successfully implemented, and that the required level of interoperability is achieved, requires comprehensive testing and evaluation.

Testing can take place in a laboratory, field location, or at an individual's workstation (during early systems designs). Typically, systems are tested at different stages in their life cycle, during development, preproduction, and in the field.

Developmental Assesses progress in meeting system-level requirements ranging from functionality to testing performance. To ensure correct intent, a system's "paper" requirements may be tested against user-stated needs.

Preproduction Conformance testing focuses on the stand-alone functionality and performance of a testing particular system in terms of stated requirements (through a paper or laboratory test).

System-to-system testing determines how well a system interoperates with other systems. It is typically performed in a laboratory where two or more systems can be interconnected. Its scope can range from "lower-layer" (e.g., communications) to "higher layer" (e.g., applications and data) interoperability.

Field testing Assesses the extent to which a system satisfies users' operational needs in a "realworld" setting.

Functional testing involves configuring systems to meet the unique demands of particular customers, integrating products with the embedded base of systems, and evaluating the resulting system of systems from the end-to-end functional perspective.

Follow-on testing assesses a system's performance after it has been fielded, reverifying interoperability periodically or as changes occur and providing a mechanism for tracking progress in addressing known problems.

Leite proposes the test assessment method summarized in Figure 8 [Leite 98]. Testing should be seen as an integral part of requirements definition and system development. Thus testing must be essentially continuous, and "stability" is a state that is never reached in any 
meaningful sense. Without ongoing feedback, initial implementations of processes and systems may interoperate satisfactorily at first, but not later [Committee 99].

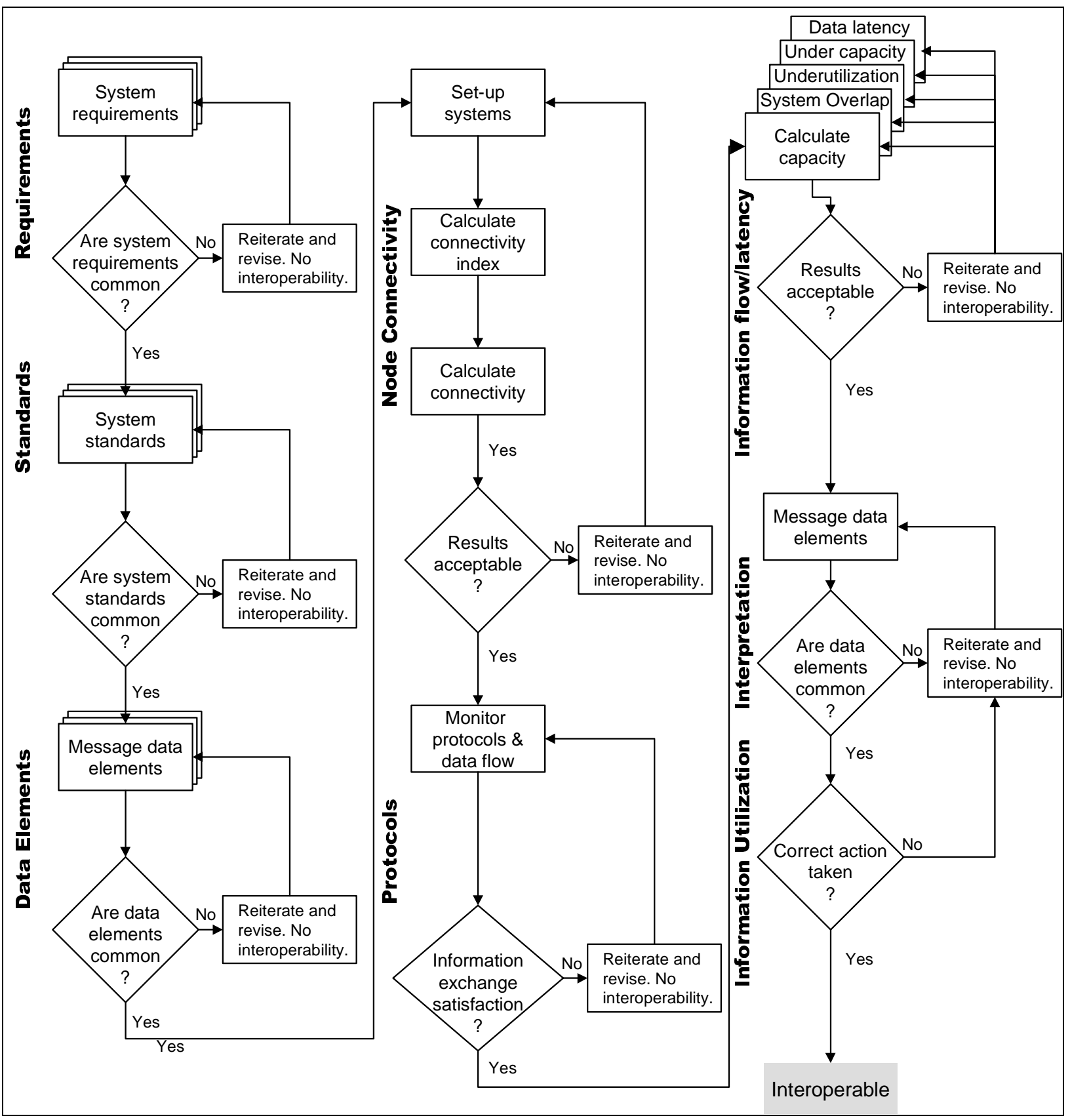

Figure 8: Interoperability Assessment Process

Often, requirements are strong in specifying behavior under ideal conditions but weak in defining what should happen under adverse situations (e.g., response of a system to failure).

Many interoperability problems are subtle and manifest themselves only in certain sets of circumstances. They are often hard to uncover and demand a great deal of empirical work 
and testing to resolve. Research on the theory and practice of interoperability testing has begun only very recently [Kang 98]. 


\section{Appendix C Potential Measures of Interoperability}

Tables 11 and 12 present potential measures (proposed by other authors) that may provide insight into interoperability. Table 12 is adapted from Kalyanasundaram [Kalyanasundaram 98].

Table 11: Software Interoperability Categorical Measures

\begin{tabular}{|c|c|}
\hline Category & Measures \\
\hline \multirow[t]{5}{*}{ Standards } & standards explicitness \\
\hline & standards maturity \\
\hline & standards vendors supporting \\
\hline & standards feature coverage \\
\hline & standards sufficiency \\
\hline \multirow[t]{7}{*}{ Profiles } & profile explicitness \\
\hline & profile width \\
\hline & profile coverage \\
\hline & profile extensions \\
\hline & use during product selection \\
\hline & profile sufficiency \\
\hline & profile documentation \\
\hline \multirow[t]{3}{*}{ Products } & products available supporting \\
\hline & product performance \\
\hline & platforms supported \\
\hline \multirow[t]{2}{*}{ Conformance } & degree of conformance \\
\hline & product-to-product interoperability \\
\hline
\end{tabular}


Table 12: Architecture Measures Related to Interoperability

\begin{tabular}{|c|c|c|}
\hline Measure & Code & Description \\
\hline Number of $3^{\text {rd }}$ party components & No3C & $\begin{array}{l}\text { The count of the number of components that have been acquired from outside } \\
\text { vendors. This measure is a reflection of the "openness" of the architecture. }\end{array}$ \\
\hline Number of components & NoC & $\begin{array}{l}\text { The total number of architectural units that can be found in the system of } \\
\text { interest. (A measure of the size of the system.) }\end{array}$ \\
\hline Number of control components & NoCC & $\begin{array}{l}\text { Number of total components that provide logical operations on a given set of } \\
\text { input data. An example of control components is a software structure that acts as } \\
\text { an iterator. This number is a subset of NoC. }\end{array}$ \\
\hline Number of data components & NoDC & $\begin{array}{l}\text { Total number of components that are passive in nature. Examples include } \\
\text { databases, stacks, and shared memory units. }\end{array}$ \\
\hline $\begin{array}{l}\text { Total number of external } \\
\text { interfaces }\end{array}$ & NoDC & $\begin{array}{l}\text { Number of connectors that allow the component to interact with other } \\
\text { components outside the system or subsystem. This is an indirect measure that } \\
\text { tries to capture the coupling in the system. }\end{array}$ \\
\hline $\begin{array}{l}\text { Total number of internal } \\
\text { interfaces }\end{array}$ & TNII & $\begin{array}{l}\text { The number of connectors that allow components to interact with other } \\
\text { components within a subsystem or layer. }\end{array}$ \\
\hline $\begin{array}{l}\text { Number of specialized } \\
\text { components }\end{array}$ & NoSC & $\begin{array}{l}\text { A count of components that are considered to have a high level of system } \\
\text { specificity. These components offer specific services, which prohibit their use in } \\
\text { any other context. This measure is based on a subjective measure provided by } \\
\text { the architects and designers. }\end{array}$ \\
\hline $\begin{array}{l}\text { Number of functionally critical } \\
\text { components }\end{array}$ & NFCC & $\begin{array}{l}\text { Counts the number of components whose failure would drastically affect the } \\
\text { systems' functionality. This is a subjective measure provided by the designers. }\end{array}$ \\
\hline $\begin{array}{l}\text { Number of shared memory } \\
\text { components }\end{array}$ & NSMC & $\begin{array}{l}\text { Shared memory is a critical component in large-scale systems with a high level } \\
\text { of criticality associated with it. }\end{array}$ \\
\hline $\begin{array}{l}\text { Number of architectural } \\
\text { revisions }\end{array}$ & NoAR & $\begin{array}{l}\text { Represents the number of changes that the architecture has gone though before } \\
\text { reaching the current productization level. }\end{array}$ \\
\hline Number of interface types & NoIT & $\begin{array}{l}\text { In large systems, several types of interactions are available. This is a measure of } \\
\text { the various interface techniques in the system. The more the NoIT, the higher } \\
\text { the complexity. }\end{array}$ \\
\hline Number of generic components & NoGC & $\begin{array}{l}\text { This is a measure of components, which are "general" in nature. These } \\
\text { components are not domain specific. (The designer would label each component } \\
\text { as generic or specialized.) }\end{array}$ \\
\hline $\begin{array}{l}\text { Number of redundant } \\
\text { components }\end{array}$ & NoRC & $\begin{array}{l}\text { In some systems, hardware components and software components are replicated } \\
\text { to recover during component failures. Redundant components are components } \\
\text { that are generally not used by the system during normal operation and which } \\
\text { usually mirror the functionality of other components in the system that are used } \\
\text { extensively. This measure is provided by the system documentation. }\end{array}$ \\
\hline
\end{tabular}




\begin{tabular}{|l|l|l|}
\hline $\begin{array}{l}\text { Number of concurrent } \\
\text { components }\end{array}$ & NCC & $\begin{array}{l}\text { The number of components that operate concurrently. Concurrency is prevalent } \\
\text { in real-time telecommunications systems. Its effect on the quality of the system } \\
\text { is significant. }\end{array}$ \\
\hline Number of subsystems & NoSS & $\begin{array}{l}\text { Represents the number of units that are logical or physical clusters or } \\
\text { components. }\end{array}$ \\
\hline Number of services & NoS & $\begin{array}{l}\text { The number of different services that are offered by a telecommunications } \\
\text { system. }\end{array}$ \\
\hline
\end{tabular}




\section{Appendix D Equations for Quality Attributes Associated with the Interoperability Scorecard}

\section{Connectivity}

A connectivity index can be calculated for any communications system. It is a relationship between the number of system nodes and the available paths. The connectivity index is defined by the equation:

$$
C_{i}=\frac{k}{n *(n-1)}
$$

Where:

$\mathrm{C}_{\mathrm{i}}=$ Connectivity index

$\mathrm{k}=$ Number of connections (paths between nodes)

$\mathrm{n}=$ Number of nodes (participating units)

Connectivity can be measured directly by counting the number of messages initiated by all participating units and the number of messages received for the network or data link. To the extent that the link is in continuous operation, the connectivity sampled in this manner is representative of network connectivity. If the network is operated intermittently, then the sample must be carefully selected and tested to ensure that the required confidence level is attained.

The general relationship for measuring the connectivity is the following:

$$
C=\left(1 / n_{r}\right) \times \frac{\sum_{y=1}^{n_{r}}\left(M_{r}\right)_{y}}{\sum_{x=1}^{n_{t}}\left(M_{t}\right)_{x}}
$$

Where:

$\mathrm{C}=$ Node Connectivity (during measurement period)

$\mathrm{n}_{\mathrm{r}} \quad=$ Number of receiving nodes

$\mathrm{n}_{\mathrm{t}} \quad=$ Number of transmitting nodes

$\mathrm{M}_{\mathrm{t}} \quad$ = Messages transmitted by a node

$\mathrm{M}_{\mathrm{r}} \quad$ = Messages received by a node

\section{Information Flow}

The volume of data is typically a function of the tempo of operations and the area of interest. The area of interest (AOI) is defined by the operational commander. The tempo of operation is event-driven; however, estimates are possible based on historical and exercise results.

Capacity is a function of the available data links. In practice, multiple links or paths are available. For weapon and combat systems, there is a requirement for primary and back- 
up paths. The redundancy of data flow limits the total capacity to an amount that is less than the sum of the individual systems.

Several items may be measured or calculated with respect to system performance. They are capacity, system overload, and data latency. The relationships for these measures follow:

\section{* Capacity}

The capacity of a system is the rate at which data may be passed over time. Given its operating parameters, a maximum data rate can be calculated for any system or group of systems. These relationships are described as follows:

$$
Q_{\text {eff }}=\left(Q_{\max }-Q_{o h}\right) \times\left(t_{f}-t_{p}\right)
$$

Where:

$$
\begin{array}{ll}
Q_{\text {eff }} & =\text { Effective system capacity (data rate) } \\
Q_{\max } & =\text { Maximum data rate } \\
Q_{o h} & =\text { System overhead data rate } \\
t_{f} & =\text { Time slot duration (unit transmission) } \\
t_{p} & =\text { Unit propagation time }
\end{array}
$$

\section{* System Overload}

A system overload occurs when more data must be exchanged than the system is able to transmit. Typically, the overload is placed in a queue and is then transmitted when capacity is available. Therefore, the measure of system overload is the sum of the messages remaining in queues after their assigned transmission period for all system nodes.

$$
M_{O L}=n_{t} \times \sum_{y=1}^{n_{r}}\left(M_{q}\right)_{y}
$$

Where:

$$
\begin{array}{ll}
M_{\mathrm{OL}} & =\text { System message overload } \\
n_{\mathrm{t}} & =\text { Number of transmitting nodes } \\
\mathrm{M}_{\mathrm{q}} & =\text { Messages in queue to be transmitted by node }
\end{array}
$$

\section{* Underutilization}

This occurs when the system data rate/message load is less than its full capacity but messages are waiting in queues to be transmitted. This occurs when the item slot or transmission allocation to selected nodes is less than that required to clear the queue by the end of a transmission period. Similarly other nodes do not use all of their allocated time.

$$
\begin{gathered}
Q_{u u}=M_{O L} \\
\text { AND } \\
Q_{u u}=Q_{\text {eff }}-Q
\end{gathered}
$$$$
\text { For } M_{O L} \leq\left(Q_{\text {eff }}-Q\right)
$$

Where:

$$
\text { For } M_{O L}>\left(Q_{e f f}-Q\right)
$$

$$
\begin{array}{ll}
\mathrm{Quu}_{\mathrm{uu}} & =\text { System Underutilization (data rate) } \\
\mathrm{Q} & =\text { Measured/observed data rate }
\end{array}
$$

(Other terms as previously defined.) 
* Undercapacity

Undercapacity occurs when messages remain in queues and the system data rate is at the maximum.

$$
Q_{u c}=\left(Q+M_{O L}\right)-Q_{e f f}
$$

Where:

Must be $>0$

$$
\mathrm{Q}_{\mathrm{uc}} \quad=\text { System undercapacity (data rate) }
$$

(Other terms as previously defined.)

\section{Data Latency}

Data latency is the elapsed time from the time of the event to the time of receipt by the user (tactical data processor). For analytical purposes, the latency is often divided into smaller segments. Several common time periods are the following:

- time of event to time of observation

- time of observation to completion of processing

- completion of processing to time of receipt at the tactical data processor

This division is useful in situations involving a remote sensor and intermediate processing to reduce the data to a usable form (track message) prior to passing the data to the user. These relationships are expressed as follows.

$$
\begin{gathered}
\overline{\Delta t}=t_{r}-t_{e} \\
\overline{\Delta t}_{o}=t_{o}-t_{e} \\
\overline{\Delta t}_{m}=t_{m}-t_{o} \\
\overline{\Delta t}_{r}=t_{r}-t_{m}
\end{gathered}
$$

Equation 8 may be rewritten as:

$$
\overline{\Delta t}=\overline{\Delta t_{o}}+\overline{\Delta t_{m}}+\overline{\Delta t_{r}}
$$

Where:

$$
\begin{array}{ll}
\Delta t & =\text { Time latency } \\
\Delta t_{o} & =\text { Latency of observation } \\
\Delta t_{m} & =\text { Latency of measurement/processing } \\
\Delta t_{r} & =\text { Latency of transmission/receipt } \\
t_{e} & =\text { Time of event } \\
t_{o} & =\text { Time of observation } \\
t_{m} & =\text { Time of completion of processing } \\
t_{r} & =\text { Time of receipt }
\end{array}
$$




\section{Information Interpretation and Utilization}

Having passed the data and correctly interpreted it, the next step would be to verify that the proper action is taken. Verification of the action taken involves a review of the logic associated with every option that is possible in response to a message or operator action. These deal with questions of interoperability and not with the difficult, higher-level topic of measuring mission effectiveness. These data would be qualitative in nature, perhaps binary (i.e., successful vs. failed). Some suggested measures in this area include

- Percentage of initial transmission messages received correctly by shooters

- Percentage of consistency/disparity of redundant data sources

- Number of tries needed to establish connections

- Delay in sending critical command messages and time to receive and acknowledge messages 


\section{References}

All URLs are valid as of the publication date.

[Army 96] Army Digitization Office. "Army Digitization Master Plan, 1996.” Army Digitization Office, Washington, D.C. March 1996.

[Bernstein 96] Bernstein, Philip A. "Middleware: A Model for Distributed Services." Communications of the ACM 39, 2 (February 1996): 86-97.

[Barbacci 95] Barbacci, M.; Klein, M.; Longstaff, T.; \& Weinstock, C. Quality Attributes (CMU/SEI-95-TR-021, ADA307888). Pittsburgh, PA: Software Engineering Institute, Carnegie Mellon University, 1995.

<http://www.sei.cmu.edu/publications/documents/95.reports/95.tr.021.html>.

[Bass 98] Bass, L.; Clements, P.; \& Kazman, R. Software Architecture in Practice. Reading, MA: Addison Wesley Publishing Company, 1998.

[Cetus 00] Cetus Links, CORBA Links.

<http://www.cetus-links.org/oo_corba.html> (2000).

[Chairman 96] Chairman of the Joint Chiefs. "Joint Vision 2010.” Joint Chiefs of Staff, Washington D.C. 1996.

[Chairman 00] Chairman of the Joint Chiefs. Joint Vision 2020.

<http://www.dtic.mil/jv2020/jvpub2.htm> (2000).

[Chatfield 98] Chatfield, J.; Enyeart, C.; \& Ficks, W. New Architecture Directions. <http://www.mitre.org/news/the_edge/january_98/fifth.html> (1998).

[Cherkaoui 99] Cherkaoui, O.; Rico, N.; \& Serhrouchni, A. "SNMPv3 Can Still Be Simple?" 501-515. Proceedings of the Sixth IFIP/IEEE International Symposium. Boston, MA, May 24-28, 1999. Piscataway, NJ: IEEE, 1999.

[C4ISR 97] C4ISR Integration Task Force. 1997. "C4ISR Integration Task Force Executive Report.” p. 27. Department of Defense, Washington, D.C. 1997. 
[C4ISR 98]

[Committee 99]

[CSTB 94]

[Dept. AF 96]

[Dept. Army 96]

[Dept. Navy 96]

[DISA 96]

[DoD 91]

[DoD 95]

[DoD 96]

[DoD 98]

[DoDD 77]
C4ISR Architecture Working Group. Levels of Information Systems

Interoperability (LISI).

<http://www.defenselink.mil/nii/org/cio/i3/lisirpt.pdf〉 (1998).

Committee to Review DoD C4I Plans and Programs. "Realizing the Potential of C4I." National Academy Press. Washington, D.C. 1999.

Computer Science and Telecommunications Board, National Research Council. "Realizing the Information Future: The Internet and Beyond." National Academy Press, Washington, D.C. 1994.

Department of the Air Force. Global Engagement: A Vision for the 21st Century. <http://www.au.af.mil/au/awc/awcgate/global/nuvis.htm> (1996).

Department of the Army. "Army Vision 2010." Department of the Army, Washington, D.C. 1996.

Department of the Navy. "Forward...From the Sea." Department of the Navy, Washington, D.C. 1996.

The Defense Information System Agency. Defense Information Infrastructure (DII) Shared Data Environment (SHADE) Capstone Document. <http://diides.ncr.disa.mil/shade> (1996).

Department of Defense Directive 8230.1-M. "DoD Data Administration." 1991.

Chairman of the Joint Chiefs of Staff, Instruction 6212.01A: "Compatibility, Interoperability, and Integration of Command, Control, Communications, Computers, and Intelligence Systems.” June 1995.

Department of Defense Directive 5000.1, "Defense Acquisition," March 15, 1996.

Joint Chiefs of Staff. "Department of Defense Dictionary of Military and Associated Terms, as amended through December 7, 1998" (Joint Publication 1-02).

DODD. "DODD 2010.6 Standardization and Interoperability of Weapon Systems and Equipment Within the North Atlantic Treaty Organization (NATO)." 11 March 1977. 
[Eldridge 78]

[GAO 98]

[Hamilton 00]

[IEEE 90]

[JCS 00]

[JINTACCS 74]

[JTAMDO 97]

[Kalyanasundaram 98]

[Kang 98]

[Kazman 00]
Eldridge, Ingrid A. "Interoperability Via Emulation." Proceedings of the 1978 Summer Computer Simulation Conference. Los Angeles, California, July 24-26, 1978. Montvale, NJ: American Federation of Information Processing Societies Press, 1978.

General Accounting Office. "Joint Military Operations: Weaknesses in DoD's Process for Certifying C4I Systems' Interoperability." GAO/AIMD98-257, General Accounting Office, Washington, D.C. 1998.

Hamilton, John A. "Joint Interoperability from the Service C4I Systems Command." Proceedings of the Software Technology Conference 2000. Salt Lake City, Utah, April 20 - May 5, 2000. Hill Air Force Base, UT: Software Technology Support Center, 2000.

"IEEE Standard Glossary of Software Engineering Terminology," IEEE Std 610.12-1990.

Joint Chiefs of Staff. Information Superiority and Space.

<http://www.defenselink.mil/execsec/adr2000/chap8.html> (2000).

“JINTACCS Interoperability.” ref-PM99, December 21, 1974.

Joint Theater Air Missile Defense Organization (JTAMDO). "JTAMDO Master Plan" Chapter 7. JTAMDO, Joint Staff, Department of Defense, Washington, D.C. 1997.

Kalyanasundaram, S.; Ponnambalam, K.; Singh, A.; Stacey, B.; \& Munikoti, R. "Metrics for Software Architecture: A Case Study in the Telecommunication Domain," 715-718, Volume II. Proceedings of the IEEE Canadian Conference on Electrical and Computer Engineering. Waterloo, Ontario, Canada, May 24-28, 1998. New York, NY: IEEE, 1998.

Kang, Sungwon. "Relating Interoperability Testing With Conformance Testing." 3768-3773, Volume VI. Proceedings of the Global Telecommunications Conference, 1998. Sydney, NSW, Australia, November 8-12, 1998. Piscataway, NJ: IEEE, 1998.

Kazman, R.; Klein, M.; \& Clements, P. ATAM: Method for Architecture Evaluation (CMU/SEI-2000-TR-004, ADA386629). Pittsburgh, PA:

Software Engineering Institute, Carnegie Mellon University, August 2000. <http://www.sei.cmu.edu/publications/documents/00.reports/00tr004.html>. 
[Koyak 99] Koyak, Robert A. "Research Opportunities in Joint Interoperability Testing." Defense Information Systems Agency. Joint Interoperability Test Command. Fort Huachuca, AZ. September 1999.

[Leite 98]

Leite, Michael J. "Interoperability Assessment." Arlington, VA: Litton PRC, June 1998.

[Marine 96]

[McCall 80]

U.S. Marine Corps. "Operational Maneuver from the Sea." Headquarters, Marine Corps, Washington, D.C. 1996.

McCall, James A. "An Assessment of Current Software Metric Research." EASCON '80. 1980. pp 323-333.

[NIMA 98]

[OUSD 99a]

National Imagery and Mapping Agency, "USIGS Technical Architecture, Revision A.” September 1998.

Office of the Under Secretary for Acquisition and Technology. Battlefield Awareness and Data Dissemination.

<http://www.acq.osd.mil/actd/00mgrenf/postconf/briefs/SU-Volz.ppt> (1999).

[OUSD 99b]

Office of the Under Secretary for Acquisition and Technology. Extending the Littoral Battlespace. <http://www.acq.osd.mil/actd/00mgrcnf/postconf/ briefs/2B-Kiepe.ppt> (1999).

[OMG 98]

Object Management Group. CORBAIIOP 2.2 Specification.

<http://www.omg.org/technology/documents/corba_spec_catalog.htm> (1998).

[Presson 83]

Presson, Edward P. "Software Metrics And Interoperability," 317-324. Proceedings of AIAA Computers in Aerospace IV Conference. Hartford, Connecticut, October 24-26, 1983. New York, NY: AIAA, 1983.

[PSM 98]

Office of the Under Secretary of Defense for Acquisition and Technology. Practical Software Measurement: A Foundation for Objective Project Management. <http://www.psmsc.com> (1998).

[SEI 00]

Software Technology Roadmap. Middleware.

<http://www.sei.cmu.edu/str/descriptions/middleware.html> 
[TMD Plan 98]

[Taylor 00]
Deputy for Theater Air \& Missile Defense, Ballistic Missile Defense Office. "Theater Missile Defense (TMD) Family of Systems (FoS) Interoperability Program Plan (IPP). Office of the Secretary of Defense, Ballistic Missile Defense Organization. Washington, D.C. 1998.

Taylor R. "Identification of Emergent Properties in a Federation." DERA/CIS/CIS3/TR000143. Defence Evaluation and Research Agency, UK. February, 2000. 


\begin{tabular}{|c|c|c|c|c|}
\hline REPORT D & 'UMENTAT & PAGE & & $\begin{array}{l}7 \text { Approved } \\
3 \text { No. 0704-0188 }\end{array}$ \\
\hline $\begin{array}{l}\text { Public reporting burden for this collecc } \\
\text { existing data sources, gathering and } 1 \\
\text { burden estimate or any other aspect } \\
\text { Directorate for information Operations } \\
\text { Budgert, Poperwork Reduction Project }\end{array}$ & 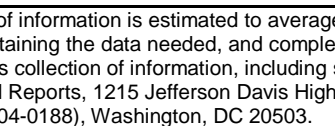 & $\begin{array}{l}\text { Tour per response, incluc } \\
\text { and revieving the collec } \\
\text { gestions for reducing this } \\
\text {, Suite } 1204 \text {, Arlington, }\end{array}$ & $\begin{array}{l}\text { e time f } \\
\text { fintorm } \\
\text { en, to W }\end{array}$ & $\begin{array}{l}\text { ewing instructions, searching } \\
\text { Send comments regarding this } \\
\text { ton Headquarters Services, } \\
\text { to the Office of Management and }\end{array}$ \\
\hline $\begin{array}{l}\text { 1. AGENCY USE ONLY } \\
\text { (Leave Blank) }\end{array}$ & $\begin{array}{ll}\text { 2. } & \text { REPORT DATE } \\
& \text { April } 2004\end{array}$ & & 3. & TTYPE AND DATES COVERED \\
\hline $\begin{array}{ll}\text { 4. } & \text { TILE ANDSUBTILE } \\
& \text { Measuring Systems Int }\end{array}$ & oerability: Challenges and & portunities & 5. $\mathrm{F}$ & $\begin{array}{l}\text { GNUMBERS } \\
28-00-C-0003\end{array}$ \\
\hline $\begin{array}{ll}6 . & \text { AUTHOR(S) } \\
& \text { Mark Kasunic, William }\end{array}$ & lerson & & & \\
\hline $\begin{array}{ll}\text { 7. } & \text { PERFORMNG ORGANZATIONN } \\
& \text { Software Engineering Ir } \\
\text { Carnegie Mellon Univer } \\
\text { Pittsburgh, PA } 15213\end{array}$ & $\begin{array}{l}\text { (S) AND ADDRESS(ES) } \\
\text { tute }\end{array}$ & & $8 . \mathrm{F}$ & $\begin{array}{l}\text { PMNG ORGANZATION } \\
\text { T NUMBER } \\
\text { SEI-2004-TN-003 }\end{array}$ \\
\hline $\begin{array}{ll}9 . & \text { SPONSORING/MONTORING AGE } \\
& \text { HQ ESC/XPK } \\
& 5 \text { Eglin Street } \\
& \text { Hanscom AFB, MA } 017\end{array}$ & $\begin{array}{l}\text { NAME(S) AND ADDRESS(ES) } \\
2116\end{array}$ & & 10. 5 & $\begin{array}{l}\text { OFING/MONTORING AGENCY } \\
\text { TNUMBER }\end{array}$ \\
\hline 11. SUPPLEMENTARY NOTES & & & & \\
\hline $\begin{array}{l}\text { 12A DISTRIBUTIONAVAALABIUTYST, } \\
\text { Unclassified/Unlimited, }\end{array}$ & $\begin{array}{l}\text { VENT } \\
\text { IC, NTIS }\end{array}$ & & $12 \mathrm{~B}$ & SUTIONCODE \\
\hline $\begin{array}{l}\text { 13. ABSTRACT (MAXIMUM } 200 \text { WOR } \\
\text { Despite laudable case-t } \\
\text { systematic basis. This t } \\
\text { military planners in the } \\
\text { computers, and intellige } \\
\text { Model, although immat } \\
\text { interoperability through } \\
\text { state of interoperability } \\
\text { and recommended mea }\end{array}$ & $\begin{array}{l}\text { case efforts, there is today } \\
\text { inical note presents best pr } \\
\text { uisition, development, and } \\
\text { (C4I) systems that are int } \\
\text { provides a structured and } \\
\text { the systems life cycle. In a } \\
\text { military applications, next s } \\
\text { es that will promote systen }\end{array}$ & $\begin{array}{l}\text { method for trackir } \\
\text { tices for measurin } \\
\text { plementation of cc } \\
\text { pperable. The Leve } \\
\text { stematic approach } \\
\text { tion to exploring th } \\
\text { s for promoting a } \\
\text { interoperability are }\end{array}$ & $\begin{array}{l}\text { terope } \\
\text { stems } \\
\text { and, } \\
\text { f Syst } \\
\text { asses } \\
\text { any c } \\
\text { per ur } \\
\text { sente }\end{array}$ & $\begin{array}{l}\text { ity on a comprehensive or } \\
\text { operability and assisting } \\
\text { ol, communications, } \\
\text { Interoperability (LISI) } \\
\text { and measuring } \\
\text { ex issues surrounding the } \\
\text { tanding of interoperability }\end{array}$ \\
\hline $\begin{array}{l}\text { 14. SUBJECT TERMS } \\
\text { Interoperability, measur } \\
\text { Interoperability (LISI) M }\end{array}$ & for interoperability, Levels & Systems & 15. 1 & ROF PAGES \\
\hline 16. PRICECODE & & & & \\
\hline $\begin{array}{l}\text { 17. SECURTYY CLASSIFCATIONOF } \\
\text { REPORT } \\
\text { Unclassified }\end{array}$ & $\begin{array}{l}\text { 18. SECURTYYCLASSIFCATION } \\
\text { OF THIS PAGE } \\
\text { Unclassified }\end{array}$ & $\begin{array}{l}\text { 19. SECURTYYCLASS } \\
\text { ABSTRACT } \\
\text { Unclassified }\end{array}$ & IONOF & $\begin{array}{l}\text { 20. UMTATION OF ABSTRACT } \\
\text { UL }\end{array}$ \\
\hline
\end{tabular}

